\title{
RENEWABLES IN ALBERTA: New Policies, New OPPORTUNities
}

\author{
Alan Ross, LEANne Desbarats, \\ RicK Williams, RoBert SHOULDice, \\ AdAM Chamberlain, AND CAROLYN MiLnE*
}

\begin{abstract}
This article explores Alberta's new climate change strategy. The authors provide an overview of the evolution of Alberta's regulatory model, point out criticisms of the preNotley regime, and evaluate the impact and effects of the new strategy. The new strategy is placed in context with federal climate change measures and analyzed in conjunction with lessons that can be learned from other jurisdictions.
\end{abstract}

\section{TABLE OF CONTENTS}

I. INTRODUCTION . . . . . . . . . . . . . . . . . . . . . . 242

II. Background on Climate Change Reform . . . . . . . . . . . . . . . 242

A. Overview of the ORIGINS OF Climate CHANGE

LEGISLATION IN ALBERTA . . . . . . . . . . . . . . . . . . . . . 242

III. THE NotLEy REGIME . . . . . . . . . . . . . . . . . . . . . . . 252

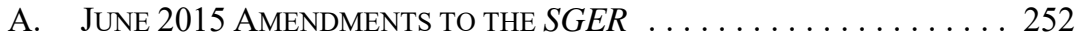

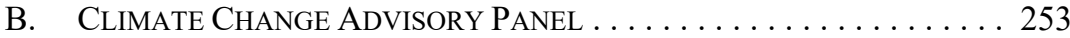

C. Climate LeAdership Report to Minister . . . . . . . . . . . . 253

IV. 2015 United Nations Climate Change Conference . . . . . . . . . 256

V. DeVElopMents After PARIS . . . . . . . . . . . . . . . . . . . . . . . . . 257

A. FEDERAL InITIATIVES . . . . . . . . . . . . . . . . . . . . 259

VI. What Will the Future Regime LoOK Like? . . . . . . . . . . . . 260

A. What Legislation Will Govern? . . . . . . . . . . . . . . 260

B. WiLl THE REGIME EXTEND BEyOND THE PANEL'S

RECOMMENDATIONS to MEET the PARIS COMMITMENTS? . . . . . . 260

C. How Will the Proposed Federal Initiatives
Interact With the Provincial Regime? $\ldots \ldots \ldots \ldots \ldots \ldots \ldots . \ldots 260$

D. WiLl THERE BE INTERJURISDICTIONAL

OFFSET AND CARBon TRADING? . . . . . . . . . . . . . 261

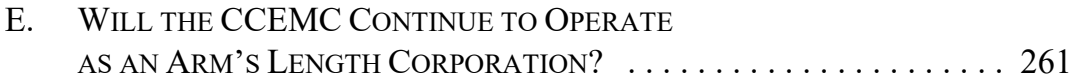

F. What Will the AESO's Clean Power EnTAil? . . . . . . . . . 262

VII. CRITIQUe ON THE EFFECTIVENESS OF THE PROVINCIAL

REGULATORY FRAMEWORK AS AN INCENTIVE FOR THE

EMERGENCE of RENEWABLE POWER . . . . . . . . . . . . . 263

VIII. WINNERS AND LOSERS: INDUSTRY IMPLICATIONS $\ldots \ldots \ldots \ldots \ldots \ldots \ldots$

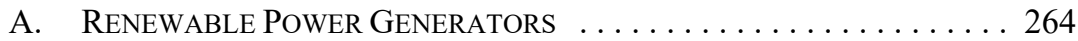

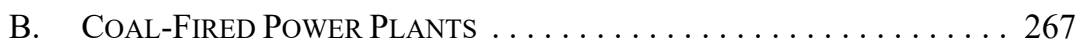

Alan Ross is a partner and Leanne Desbarats is an associate at the Calgary office of Borden Ladner Gervais LLP. Rick Williams and Robert Shouldice are partners at the Vancouver office of Borden Ladner Gervais LLP. Adam Chamberlain is a partner at the Toronto office of Borden Ladner Gervais LLP. Carolyn Milne is legal counsel at Shell Canada. The Canadian Energy Law Foundation does not necessarily endorse the contents or the opinions presented in this article. 
C. Natural Gas Producers . . . . . . . . . . . . . . . . . . . 269

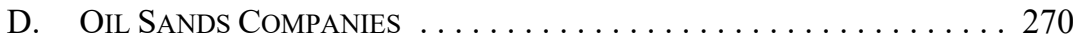

E. Pipeline Project Proponents $\ldots \ldots \ldots \ldots \ldots \ldots . \ldots \ldots$

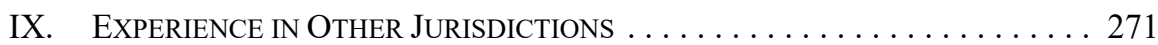

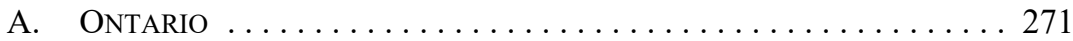

B. BRITISH COLUMBIA . . . . . . . . . . . . . . . . . . . . . . . . . . 274

X. CONCLUSION ............................ 278

\section{INTRODUCTION}

On 15 November 2015, Alberta Premier Rachel Notley announced a far-reaching and comprehensive new provincial strategy with respect to climate change which had significant impacts on oil and gas companies and electric utilities in Alberta. The announcement, which came on the heels of provincial climate change reforms introduced earlier in August 2015, responded to recommendations made by the government-appointed Climate Change Advisory Panel, and fulfilled the Premier's promise to disclose Alberta's new climate change policy initiatives prior to the commencement of the 21 st Conference of the Parties of the United Nations Framework Convention on Climate Change held in Paris. While the government continues to announce the specific reforms that accompany this strategy, it is anticipated that the ensuing consequences of these reforms will dramatically alter the industry and economic landscape in Alberta and beyond.

This article will address the origins and evolution of Alberta's legislative initiatives with respect to climate change, identifying the contextual factors and specific policy initiatives that have shaped Alberta's unique regulatory model. The article will then discuss some prevailing criticisms of the pre-Notley regime and analyze how effectively the new climate initiatives address those concerns. The article will discuss the impacts of the recent provincial strategy, focusing on the resulting effects on the oil and gas and electricity industries in Alberta, identifying emerging industry responses, opportunities and challenges, and the winners and losers among the stakeholders. The effectiveness of the regulatory framework as an incentive for renewable power development will be critically assessed and finally, the interface of Alberta's initiatives with federal climate change measures and the lessons that can be learned from other Canadian jurisdictions will also be discussed.

\section{BACKgRound on Climate Change Reform}

\section{A. Overview of the Origins of Climate Change LEGISLATION IN ALBERTA}

\section{INTRODUCTION OF THE CLIMATE CHANGE AND EMISSIONS MANAGEMENT ACT}

Alberta was a leader on the issue of climate change in Canada, introducing the first legislation regulating the emission of greenhouse gases (GHGs) in the country in 2003 with the Climate Change and Emissions Management Act. ${ }^{1}$ The CCEMA is the backbone of 
Alberta's regulatory regime with respect to the regulation of GHG emissions and its design reflects Alberta's unique approach to addressing climate change.

The impetus for the introduction of the CCEMA was the Kyoto Protocol, ${ }^{2}$ signed by Canada in 1997. Alberta's strong reaction against the Kyoto Protocol ${ }^{3}$ prompted the provincial government to introduce its own "made-in-Alberta"4 regulatory framework in an effort to pre-emptively assert its jurisdiction over the regulation of natural resources and to influence policy at the federal level. ${ }^{5}$ While Canada withdrew from the Kyoto Protocol in $2011,{ }^{6}$ the Kyoto Protocol was influential in terms of the design and details of the CCEMA and Alberta's regulatory model is best assessed and understood in this context. ${ }^{7}$

In the lead up to the introduction of the CCEMA, ${ }^{8}$ the then provincial government was vocal in its opposition to ratifying the Kyoto Protocol, asserting that ratification would be "disastrous" for Alberta as a growing energy player. ${ }^{9}$ Alberta's position, that the provinces, and not the federal government, have the constitutional jurisdiction to regulate GHG emissions is addressed directly in the preamble to the CCEMA which provides:

Kyoto Protocol to the United Nations Framework Convention on Climate Change, 11 December 1997, 2303 UNTS 148 at 218 (entered into force 16 February 2005) [Kyoto Protocol].

Government of Alberta, News Release, "Alberta to Press for Binding Commitment Before Signing on to Kyoto Agreement"(11 December 1997), online: <alberta.ca/acn/199712/5712.html>;"Premier Klein Overstates Kyoto Climate Deal's Impact on Alta Economy: Experts," Canadian Press Newswire (24 July 2001).

4 Alberta, Legislative Assembly, Hansard, 25th Leg, 3rd Sess (18 November 2003) at 1707 (Hon Dave Broda) [Hansard, 18 November 2003].

$5 \quad$ Nathalie J Chalifour, "Making Federalism Work for Climate Change: Canada's Division of Powers Over Carbon Taxes" (2008) 22:2 NJCL 119 at 126.

6 Environment and Climate Change Canada, "A Climate Change Plan for the Purposes of the Kyoto Protocol Implementation Act 2012" (9 June 2012), online: <ec.gc.ca/Publications/default.asp?lang= En\&n=EE4F06AE-1\&xml=EE4F06AE-13EF-453B-B633-FCB3BAECEB4F\&offset=3\& toc=hide $>$. For example, some clear impacts of the Kyoto Protocol on the CCEMA are the adoption of 1990 as the benchmark for reductions and a definition of "specified gases" mirroring the "six main greenhouse gases" targeted for reductions by the Kyoto Protocol. See United Nations Framework Convention on Climate Change, Kyoto Protocol Reference Manual on Accounting of Emissions and Assigned Amount, online: UNFCCC $<$ unfccc.int/resource/docs/publications/08_unfccc_kp_ref_manual.pdf $>$; CCEMA, supra note 1, s 3; Kyoto Protocol, supra note 2, art 3(1).

8 The introduction of CCEMA was preceded by Bill 32, Climate Change and Emissions Management Act, 2nd Sess, 25th Leg, Alberta, 2003, which was given first reading 19 November 2002 and second reading 26 November 2002 but did not pass in the 2 nd session of the 25 th legislature. Bill 32 was quite similar in substance to the CCEMA but differed in some key respects. For further analysis of Bill 32 and the introduction of the CCEMA, see Nigel D Bankes \& Alastair R Lucas, "Kyoto, Constitutional Law and Alberta's Proposals" (2004) 42:2 Alta L Rev 355.

$9 \quad$ See e.g. Alberta Environment, Albertans \& Climate Change: A Strategy for Managing Environmental \& Economic Risks (Edmonton: Government of Alberta, February 2002) at 5-7, online: < https://extranet. gov.ab.ca/env/infocentre/info/library/5895.pdf>, where it provides that Kyoto would "be nothing short of disastrous" for the province; see also the rhetoric used in introducing the CCEMA as a bill in the legislature: Alberta, Legislative Assembly, Hansard, 25th Leg, 2nd Sess, (26 November 2002) (Hon Premier Klein). Then-Premier Klein stated:

This is the assurance we need to give industry in this province, that we are doing everything in our power to protect the Alberta advantage and to protect what is our responsibility under the Constitution and our jurisdiction under the Constitution. We will protect - we will protect Albertans from the federal government's political agenda, and we will protect it by reinforcing the province's ownership and control over natural resources (ibid at 1535).

See also Government of Alberta, News Release, "Alberta Tables Climate Change Action Plan and Progress Report at Environment and Energy Ministers Meeting" (20 November 1995), online: $<$ alberta.ca/acn/199511/3166.html>; Steven Chase, "Alberta Urges Provinces to Abandon Kyoto Accord," The Globe and Mail (23 May 2002), online: <www.theglobeandmail.com/news/national/ alberta-urges-provinces-to-abandon-kyoto-accord/article1023571/>. 
WHEREAS the Government of Alberta owns natural resources in Alberta on behalf of all Albertans and manages the exploration, development and production of renewable and non-renewable resources in Alberta. $^{10}$

While the expected "major constitutional battle" that many predicted when the CCEMA was introduced never materialized, ${ }^{11}$ the tension between federal and provincial authority over the regulation of GHGs has never been fully resolved. ${ }^{12}$ As discussed further in this article, while the provincial and federal governments appear to be working harmoniously in developing a federal climate change policy that complements the new Alberta policies, any perceived unfavourable treatment of the provinces by the federal government could renew this standoff.

The most notable feature of the CCEMA is that it is an emissions-intensity regime. ${ }^{13}$ This regime calls for a reduction of "specified gases" relative to Canada's gross domestic product as opposed to a regime based on absolute reduction amounts, as recommended in the Kyoto Protocol, ${ }^{14}$ which the Alberta government presented as a being a less "rigid and inflexible" alternative to the Kyoto Protocol. ${ }^{15}$ As will be further discussed in this article, this has proven to be a controversial aspect of Alberta's regulatory regime, given that it allows for overall emissions to increase in a growing economy.

\section{Structure of the Climate Change EMISSIONS MANAGEMENT ACT}

The CCEMA creates an intensity-based limit on industrial GHG emissions and sets out, as a province-wide goal, a reduction in "specified gases" relative to the province's GDP by at least 50 percent of the province's emissions levels as they existed in $1990 .{ }^{16}$ The CCEMA provided for an economy-wide reduction, and while the later amendments limited the requirement to reduce emissions in Alberta to large industrial emitters, the CCEMA is broader in application and would not need to be revised or replaced to expand the applicability of emissions reductions in the future. ${ }^{17}$

\section{PRE-2015 SPECIFIED GAS EMITTERS REGULATION}

The key piece of legislation that compels the reduction of GHG emissions is the Specified Gas Emitters Regulation which was proclaimed into force on 20 April 2007, with the reduction targets prescribed for in the regulation taking effect on 1 July $2007 .{ }^{18}$ The SGER

EMA, supra note 1, Preamble.

Shi-Ling Hsu \& Robin Elliot, "Regulating Greenhouse Gases in Canada: Constitutional and Policy Dimensions" (2009) 54:3 McGill LJ 463 at 465.

12 For further discussion about the constitutional grounds that could be raised if such a dispute were to arise, see Peter W Hogg, "Constitutional Authority Over Greenhouse Gas Emissions" (2009) 46:2 Alta L Rev 507; Bankes \& Lucas, supra note 8.

CCEMA, supra note $1, \mathrm{~s} 3(1)$.

Kyoto Protocol, supra note 2, art 3(1) provides that the signatories will reduce "their overall emissions of such gases by at least 5 per cent below 1990 levels in the commitment period 2008 to 2012."

Hansard, 18 November 2003, supra note 4 at 1708.

CCEMA, supra note 1, s 3(1). "[S]pecified gas" is defined as, "any gas that traps heat near the earth's surface and includes, without limitation, carbon dioxide, methane, nitrous oxide, hydrofluorocarbons, perfluorocarbons and sulphur hexafluoride" (ibid, s $1(\mathrm{~g})$ ).

Ibid, s 3.

Specified Gas Emitters Regulation, Alta Reg 139/2007 [SGER]. 
only applies to large industrial facilities. ${ }^{19}$ As discussed further below, the SGER was amended in 2015 (the 2015 SGER Amendments) and it is expected that it will undergo further changes in the future. The 2015 SGER Amendments did not significantly change the structure of the legislation. An overview of the details of the regime created by SGER is therefore important to understand the impacts of the 2015 SGER Amendments, how those amendments addressed the criticisms of the regime, and how the SGER could be revised in the future.

Under the SGER, the regulation of emissions is intensity-based. Facilities can increase their absolute emissions from year-to-year so long as the per-unit emissions level is reduced. ${ }^{20}$ The model requires that the facility make improvements each year based off of the facility's own emissions profile. This is a key characteristic of the regime, as a facility is only compared to itself and not to its peers.

The SGER provides for four compliance options that a facility can use to meet its obligations: (1) improving the energy efficiency of its operations, ${ }^{21}(2)$ making payments into the Climate Change and Emissions Management Fund (the CCEMF or the Fund); ${ }^{22}$ (3) purchasing emission offsets; ${ }^{23}$ or (4) using previously generated emission performance credits. ${ }^{24}$ There is no limit to the use of these four options to meet reduction obligations under the SGER.

\section{a. Improving Energy Efficiency}

The first option a facility can use in achieving its emissions reduction targets is to reduce its emissions intensity. ${ }^{25}$ The SGER requires facilities that emit 100,000 tonnes of GHGs or more annually to reduce their emissions intensity based on a formula. ${ }^{26}$

Prior to the 2015 SGER Amendments, an established facility ${ }^{27}$ was required to make a 12 percent reduction from a facility's baseline emissions intensity (BEI) ${ }^{28}$ For a new facility, ${ }^{29}$ under the pre-2015 version of SGER no reduction was required in the first three years of operation and then a 2 percent reduction was required for each additional year a facility

Ibid, s 2. Under the CCEMA, supra note 1, the government may make regulations: (1) "establishing interim specified gas emission targets" (ibid, s 3(2)(a)); and (2) "establishing specified gas emission targets and interim specified gas emission targets for different specified gases and for different sectors of the Alberta economy" (ibid, s 3(2)(b)). These provisions allowed the government to create the SGER, which only applies to a particular sector of the economy, large industrial facilities (ibid, s 3 ).

SGER, ibid, s 6.

Ibid, $\mathrm{s} 7$.

Ibid, $\mathrm{s} 8(2)$ provides that the price of a contribution to the Fund is to be set by ministerial order. As such, the amount of the Fund contribution can be amended very easily.

Ibid, s 7.

Ibid, s 9(1).

Ibid, $\mathrm{s} 7$.

Ibid, ss 2,7 .

Ibid, s 1(1)(i). An "established facility" is defined in the SGER as "a facility that completed its first year of commercial operation before January 1, 2000, or [had] completed 8 years of commercial operation." Ibid, s 21(1). The BEI for an established facility was based on the ratio of the total annual emissions of production for 2003 to 2005.

Ibid, s 1(1)(p). A "new facility" is defined in the SGER as "a facility that completed its first year of commercial operation [after 1 January 2000] and has completed less than 8 years of commercial operation." 
operated, up to a 10 percent reduction requirement for facilities in the eighth year of operation at the end of $2007 .^{30}$

b. Technology Fund

If a facility cannot meet its emissions reduction target as prescribed by the CCEMA and the SGER, it also has the option of contributing to the CCEMF. Under the pre-2015 SGER such a contribution was at a rate of $\$ 15$ per tonne to receive a credit (a Fund Credit). ${ }^{31}$

\section{c. Purchase of Emission Offsets}

A facility can also elect to purchase emissions offsets (Emissions Offsets) to satisfy its emission reduction requirements under the CCEMA. ${ }^{32}$ The Emissions Offsets are created when a non-regulated activity voluntarily reduces GHG emissions in accordance with the SGER and in a manner that can be quantified using an approved quantification protocol (an Offset Protocol). The Emissions Offsets can then be purchased by a regulated facility. Under the SGER, one tonne of carbon dioxide (CO2) reduced is equal to one Emissions Offset credit. ${ }^{33}$ Emissions Offsets need to be registered and serialized on the Alberta Emission Offset Registry (the Registry) before becoming a tradeable unit that can be bought and sold in the Alberta offset market. ${ }^{34}$

Emissions Offsets are created following an Offset Protocol which describes the project type and specifies how it is quantified. To be eligible under the Alberta system, the Emissions Offsets must come from a voluntary action and meet a number of criteria: (1) the specified gas emission reduction must occur in Alberta; (2) the specified gas emission reduction must be from an action taken that is not otherwise required by law at the time the action is initiated; (3) the specified gas emission reduction must result from actions taken on or after 1 January 2002, and occur on or after 1 January 2002; (4) the specified gas emission reduction must be "real and demonstrable"; and (5) the specified gas emission reduction must be quantifiable and measurable, directly or by using replicable techniques. ${ }^{35}$

The reductions or removals must be generated from actions that have "additionality," in that they are beyond regulatory requirements and business as usual or sector common practices. ${ }^{36}$ For the specified gas emissions reduction to be "real," "demonstrable," and "quantifiable," the project must demonstrate that it causes a net reduction in GHGs regulated

Ibid, s 4(1)(b). The BEI for a new facility was based on the annual emissions from the third year of commercial operation of the facility divided by the production in the third year (ibid, s 21).

Ibid, s 8(2) provides that the price of a Fund Credit is to be set by ministerial order; Ministerial Order 13/2015, (2015), online: <aep.alberta.ca/climate-change/guidelines-legislation/specified-gas-emittersregulation/documents/ClimateChangeEmissionsFund-MO-13-2015.pdf>.

SGER, supra note $18, \mathrm{~s} 7$.

Ibid, s 7(1.4).

Government of Alberta, Technical Guidance for Offset Project Developers (Edmonton: Government of Alberta, February 2013) at 7, online: < https://extranet.gov.ab.ca/env/infocentre/info/library/8525.pdf > [Technical Guidance]. 
under the CCEMA, and the reductions must be quantified according to accepted methodologies in the approved Offset Protocols. ${ }^{37}$

Emissions Offsets are bought and sold privately. However, all status changes are tracked by the Registry. While the specified emissions reductions must be made in Alberta, and while Emissions Offsets need to be registered and serialized on the Registry before becoming a tradeable unit that can be bought and sold in the Alberta offset market, there is no requirement that Emissions Offsets remain in Alberta, and they can be sold to voluntary markets in other jurisdictions. ${ }^{38}$

\section{d. Emission Performance Credits}

Another compliance mechanism under the pre-2015 SGER and the current SGER is the ability to generate or purchase emissions performance credits (EPCs) from a regulated facility that reduces its emissions below its emissions intensity requirement. ${ }^{39}$ One EPC is available for each tonne that the facility's emissions are below its prescribed target. ${ }^{40} \mathrm{EPCs}$ can be used in future years by the facility generating them or by any other facility (but only for the same year it was created). ${ }^{41}$

\section{2008 AMENDMENTS TO THE CCEMA}

In 2008, the CCEMA was revised as part of a broader climate change strategy. ${ }^{42}$ The Climate Change Emissions Management Amendment Act, 2008 (the 2008 CCEMA Amendments) made a number of key changes to the CCEMA, including: (1) providing for the intensity targets set in the 2002 plan to be reached by 2010; (2) for GHG emissions to be stabilized by 2020; and (3) for an absolute GHG emission reduction of 14 percent below 2005 levels by $2050 .^{43}$ The 2008 CCEMA Amendments also intensified the requirements under the CCEMA, in particular by providing for specific offences, ${ }^{44}$ penalties ${ }^{45}$ administrative penalties, ${ }^{46}$ and broad rights of investigation. ${ }^{47}$ The 2008 CCEMA Amendments delegated the investment of the Fund to an arm's length not-for-profit organization, the Climate Change and Emissions Management Corporation (the CCEMC) ${ }^{48}$ and specified that the Fund is to be used only "for purposes related to reducing emissions of

Ibid. There are currently 34 Offset Protocols: Alberta Environment and Parks, "Offset Credit System Protocols"(Edmonton: 4 October 2016), online: $<$ aep.alberta.ca/climate-change/guidelines-legislation/ specified-gas-emitters-regulation/offset-credit-system-protocols.asp $x>$. There are also a number of protocols that have been terminated and are no longer available for use in the Alberta offset system.

SGER, supra note $18, \mathrm{~s} 7$.

Ibid, ss $1(1)(\mathrm{g}), 9$.

Ibid, s $9(1)$.

Ibid, s 9(2)(a).

Government of Alberta, Alberta's 2008 Climate Change Strategy: Responsibility/Leadership/Action (Edmonton: Government of Alberta, 2008), online: <www.assembly.ab.ca/lao/library/egovdocs/2008/ alen/164445.pdf> [2008 Strategy].

Ibid at 7.

CCEMA, supra note $1, \mathrm{~s} 44$.

Ibid, $\mathrm{s} 45$.

Ibid, s 38 .

Ibid, ss 11-28. By way of an example, as a result of the 2008 CCEMA Amendments, the penalty for any failure to comply with the emissions intensity limits is $\$ 200$ for every tonne of specified gases which exceeds the emissions intensity limit.

Alberta, Legislative Assembly, Hansard, 27th Leg, 1st Sess (26 May 2008) at 958. 
specified gases or supporting Alberta's ability to adapt to climate change" and included a non-exhaustive list of potential purposes. ${ }^{49}$

At the time of the introduction of the 2008 CCEMA Amendments, the official government opposition expressed concern over the delegation of authority to a non-government entity, in particular noting that this could hamper future national and international emissions trading regimes. ${ }^{50}$ As will be further discussed below, these concerns have renewed relevance under the new Climate Leadership Plan because of the significant increase in expected revenue from the Fund and the renewal of conversations about the potential for more cooperation with respect to emissions trading across jurisdictions.

One interesting change made as a result of the 2008 CCEMA Amendments was the removal of the right of the Minister to enter into agreements for interjurisdictional cooperation. That provision was replaced with a prohibition on entering into any agreements under the Government Organization Act ${ }^{51}$ providing for cooperation, or complementary or compatible actions with other jurisdictions in respect of specified gas emissions unless the agreement is consistent with the CCEMA and with the specified gas emission target for Alberta. ${ }^{52}$ Unless amended, this provision could prove to be a statutory roadblock to interjurisdictional cooperation in the future.

\section{CRITICISMS OF THE PRE-Notley Regime}

The Alberta regime that existed prior to the 2015 election of the New Democratic Party in Alberta (the Pre-Notley Regime) was criticized on a number of grounds. The most common of these are outlined below.

a. The Structure of the Emissions-Intensity

Regime Does Not Reduce Emissions

One fundamental criticism of the SGER has been that it is based on emissions intensity and, as such, allows for overall emissions to grow and does not provide for an aggregate or total cap on emissions. Accordingly, it was anticipated that no actual emissions reductions, in absolute terms, would take place in Alberta and that the legislative initiatives would only, at best, reduce the rate of increase in emissions in, what was then, Alberta's growing economy. ${ }^{53}$

For example, in the 2008 Strategy, the government expressly noted that with the growth rates in the province, it was expected that the province's total emissions by 2020 , even assuming that mitigation measures would reduce intensity, would still be 1.5 times greater

CCEMA, supra note $1, \mathrm{~s} 10(3)$.

Alberta, Legislative Assembly, Hansard, 27th Leg, 1st Sess (28 May 2008) at 1051-52 (Hon Hugh MacDonald) [Hansard, 28 May 2008].

RSA 2000, c G-10.

CCEMA, supra note $1, \mathrm{~s} 8$.

Alastair Lucas, “The Alberta Energy Sector's Voluntary Approach to Climate Change: Context, Prospects, and Limits" in G Bruce Doern, ed, Canadian Energy Policy and the Struggle for Sustainable Development (Toronto: University of Toronto Press, 2005) 293 at 293. 
than the 1990 levels. ${ }^{54}$ Since the regime "allows for an overall growth in emissions," 55 many have commented that it does not actually achieve the legislation's stated objectives in reducing emissions and addressing climate change. ${ }^{56}$ Similarly, commentators have argued that an emissions-intensity regime is weaker than other regimes, for example, a cap-and-trade or carbon pricing system, in incentivizing emissions reductions. ${ }^{57}$

Another criticism of Alberta's emissions-intensity model is that it results in an effective economic cap on the amount companies are incentivized to spend on compliance. As there is no limit on the use of the four compliance options to meet reduction obligations, the fixed contribution rate of $\$ 15$ per tonne to the Fund acts as a price ceiling and there is no incentive for emitters to consider any option with a cost higher than $\$ 15$ per tonne. ${ }^{58}$ In Alberta, since the implementation of the SGER, approximately half of the facilities have chosen to pay into the Fund. ${ }^{59}$ While Fund contributions must ultimately be used "for purposes related to reducing emissions of specified gases or improving Alberta's ability to adapt to climate change," $" 60$ an overreliance on the use of the Fund is indicative of companies having not been incentivized to make meaningful upgrades to their facilities that would reduce emissions.

\section{b. The Scope of the SGER is Too Narrow}

The scope of the SGER has also been heavily criticized. ${ }^{61}$ As the SGER only applies to large industrial emitters, critics have stated that opportunities to make reductions elsewhere were not explored. In 2013, 100 facilities in the province fit the requirements to be characterized as a large industrial facility, which represented approximately 45 percent of the total provincial emissions. ${ }^{62}$ As a corollary, there are no emissions reduction requirements for 55 percent of emissions generated in the province. If the threshold under the SGER is reduced to 50,000 tonnes of carbon per year, 147 additional facilities in Alberta would be covered. $^{63}$

2008 Strategy, supra note 42 at 23-24.

Andrew Read, "Auditor General's Scathing Review Ups Pressure to Improve Alberta's Weak Climate Policy" (10 July 2014) Pembina Institute (blog), online: <www.pembina.org/blog/auditor-generalsscathing-review-ups-pressure-to-improve-albertas-weak-climate-policy> [Read, "Auditor General's Scathing Review"].

Ibid.

Ibid. See also Andrew Leach, "Policy Forum: Alberta's Specified Gas Emitters Regulation” (2012) 60:4 Can Tax J 881 at 882, online: <https://www.ualberta.ca/business/-/media/167515D24FBC4AE59D74 107CDF4052E7>.

Andrew Read, "Climate Change Policy in Alberta," Pembina Institute (July 2014) at 3, online: <www. pembina.org/reports/sger-climate-policy-backgrounder.pdf>.

Read, “Auditor General's Scathing Review," supra note 55.

CCEMA, supra note 1 , s 10(3).

Dave Sawyer, "Regulating Carbon Emissions in Canada: A Timbit with that Double-Double? Costs and Emission Reductions of Renewed Carbon Policy in Alberta," International Institute for Sustainable Development(June 2014), online: <iisd.org/sites/default/files/publications/costs_emission_reductions_ renewed_carbon policy_alberta.pdf $>$.

Government of Alberta, Climate Leadership Discussion Document (Edmonton: Government of Alberta, August 2015) at 21, online: <alberta.ca/albertacode/images/Climate-Leadership-Discussion-Document. pdf $>$ [Discussion Document].

Ibid. 


\section{c. Ineffective Execution by Government}

The Auditor General of Alberta audited aspects of the Pre-Notley Regime in 2008, ${ }^{64}$ $2009,{ }^{65} 2011,{ }^{66}$ and $2014 .{ }^{67}$ In all of the Auditor General's reports, the implementation and execution of the CCEMA and SGER were criticized. For example, in 2014 the Auditor General noted that there was ineffective planning and monitoring of the regime, that emissions reductions had been overstated, particularly for carbon capture and storage and could not be achieved, and that the government lacked a definitive plan to achieve its stated objectives on the timelines outlined under the SGER. ${ }^{68}$

\section{d. Cogeneration}

Another criticism of the Pre-Notley Regime is that cogeneration was not directly addressed in SGER. Cogeneration is the combined generation of thermal energy and electric power from a single fuel source and is energy efficient as it derives two types of energy from a single fuel source. While guidance documents from the government addressed cogeneration and noted the government's desire "not ... to create disincentive for the cogeneration operators for their efficient use of fuels," ${ }^{69}$ there was no express treatment of cogeneration in the SGER.

In practice, cogeneration fit into the Pre-Notley Regime in the form of EPCs calculated by comparing actual emissions from a facility with cogeneration with a calculated hypothetical level of emissions that would have occurred had heat and power been generated separately. ${ }^{70}$ Emissions from both heat and power were subject to the SGER target, but a cogeneration credit (calculated based on a hypothetical natural gas combined cycle plant with an emissions intensity of 0.418 tonnes $\mathrm{CO} 2 \mathrm{e}$ per $\mathrm{MWh}$ ), was subtracted from the facility's total emissions. ${ }^{71}$

The treatment of cogeneration emissions through EPCs has been criticized on the basis that the such treatment is not adequately formalized in the regime and, in particular because

Alberta, Auditor General, Report of the Auditor General of Alberta (Edmonton: Auditor General, 2008), online: <oag.ab.ca/webfiles/reports/Oct_2008_Report.pdf>.

65 Alberta, Auditor General, Report of the Auditor General of Alberta (Edmonton: Auditor General, 2009), online: <oag.ab.ca/webfiles/reports/OAGOct2009report.pdf>.

Alberta, Auditor General, Report of the Auditor General of Alberta (Edmonton: Auditor General, 2011), online: <oag.ab.ca/webfiles/reports/OAGNov2011report.pdf>.

Alberta, Auditor General, Report of the Auditor General of Alberta (Edmonton: Auditor General, 2014), online: <oag.ab.ca/webfiles/reports/AGJuly2014Report.pdf>.

$68 \quad$ Ibid at 44.

69 Government of Alberta, Specified Gas Emitters Regulation: Additional Guidance on Cogeneration Facilities (Edmonton: Government of Alberta, 1 October 2007) at 3, online: <assembly.ab.ca/lao/library/ egovdocs/2007/alen/165318.pdf> ["SGER: Additional Guidance"].

$70 \quad$ Nigel Bankes, Giorilyn Bruno \& Cairns Price, "The Legal and Regulatory Treatment of Cogeneration in Alberta" (2015) 53:2 Alta L Rev 383 at 413-17.

71 "SGER: Additional Guidance," supra note 69. This exemption occurred through the BEI calculation and is based on the deemed emissions from electricity and thermal energy. For thermal, the deemed emissions were based on the emissions that would be produced by a hypothetical 80 percent efficient boiler. For electricity, the deemed emissions were based on a hypothetical natural gas combined cycle plant with an emissions intensity of 0.418 tonnes $\mathrm{CO} 2 \mathrm{e}$ per MWh. The reason for the use of these hypotheticals is that the policy assumes that in the absence of cogeneration, the power producer would have had to build a plant to build electricity and the heat host would have had to build an industrial boiler to generate steam. 
of the widespread use of cogeneration EPCs in Alberta, arguably a more formal recognition of cogeneration is merited. ${ }^{72}$

Another issue that has been raised is that cogeneration is business as usual and that even if there were no EPCs for cogeneration, facilities would still use it. Some have argued that without a level of "additionality," which is supposed to be a feature of the SGER regime, ${ }^{73}$ the incentives under the SGER regime are not being properly leveraged to encourage behaviour that goes beyond business as usual. ${ }^{74}$

e. Issues Over the Ownership of Emission Offsets, Fund Credits, and EPCs

The SGER provides that Emission Offsets, Fund Credits, and EPCs are "revocable licences authorizing persons responsible ... to use the emission offsets, fund credits and emission performance credits in meeting net emissions intensity limits." 75 Further, the SGER provides that "[n] othing in this Regulation ensures or guarantees the availability of emission offsets or emission performance credits." 76

However, the concept of a "revocable licence" is not well-defined and the regime does little to clarify the nature of the rights or obligations associated with Emissions Offsets, EPCs, and Fund Credits. This conceptual uncertainty, and the fact that the trading price for Emissions Offsets and EPCs are not publically reported, may make it difficult to integrate Alberta's market with other jurisdictions.

\section{f. No Adjustment for Inflation}

Critics have also suggested that the monetary thresholds in SGER became less incentivizing each year as the prices are not adjusted for inflation. ${ }^{77}$

\section{g. Uncertainty in Use of Offset Credits}

Under the SGER, an Offset Credit is never certified by the government as being compliant with the regulatory requirements until the Offset Credit is purchased by a facility. This creates risk for project developers since an Offset Credit may wind its way through the entirety of the offset creation cycle only to ultimately be rejected. If found to be noncompliant, the Emissions Offset can be disallowed creating uncertainty and potential liability

See Ana Maria Radu, “Alberta Reviews Compliance with the Specified Gas Emitters Regulation” (15 January 2014), ABlawg (blog), online: <ablawg.ca/wp-content/uploads/2014/01/Blog_AMR_SGER January-2014.pdf> (the "2012 Greenhouse Gas Emission Reduction Program Results" report release $\bar{d}$ in November 2013 provides that 3.2 Mt of CO2e were offset through cogeneration in 2012).

Sawyer, supra note 61 .

Ibid. See also Nigel Bankes, "The SGER Amendments and the New Treatment of Cogeneration" (14 July 2015), ABlawg (blog), online: <ablawg.ca/wp-content/uploads/2015/07/Blog_NB_SGERamend ment final_july2015.pdf $>$.

SGE $\bar{R}$, supra note 18 , s $10(1)$

Ibid, s 10(2).

Sawyer, supra note 61 at 7. 
for a buyer. In practice, this has caused Emissions Offsets to trade at a significant discount relative to other compliance options. ${ }^{78}$

h. The Made in Alberta Focus Limits Interjurisdictional

Cooperation on Emissions Reductions

Some critics have stated that the "made in Alberta" nature of the regime in Alberta is, itself, the basis for some of its shortcomings. One assertion is that national and international companies are not able to "manage their global carbon profile in an integrated and market wise manner" 79 because Alberta-based projects must comply with an Alberta specific regime. Further, it has been said that the Alberta model has barriers in terms of integration with other carbon markets. ${ }^{80}$ As mentioned previously, the delegation to the CCEMC of the management of the Fund revenue has also been criticized on the basis that the structure lacks a degree of government oversight that may deter interjurisdictional cooperation. ${ }^{81}$

\section{The NotLey Regime}

\section{A. JUNE 2015 AMENDMENTS TO THE SGER}

Shortly after the New Democratic Party was elected in Alberta under the leadership of Rachel Notley, the Minister of Environment and Parks, Shannon Phillips, announced that the $S G E R$ would be renewed for a period of two years with significant amendments. She described the amendments as "interim measures" until such time as the government's new climate strategy was completed. ${ }^{82}$ The 2015 SGER Amendments touch on two key aspects of the SGER. First, the intensity reduction requirements have increased. By 1 January 2016, large emitters will have to reduce emissions intensity by 15 percent, which will increase to 20 percent by 1 January $2017 .{ }^{83}$ Second, the carbon levy will be increased from $\$ 15$ per tonne to $\$ 20$ per tonne for 2016 , and to $\$ 30$ per tonne for $2017 .{ }^{84}$

Another notable change to the SGER was the inclusion of a specific provision dealing with cogeneration. ${ }^{85}$ The 2015 SGER Amendments revised section 6 of the SGER to include a new variable in the formula for determining the net emissions intensity for a facility providing that "CCA is the cogeneration compliance adjustment for the year." 86 The SGER provides that a definition for "cogeneration compliance adjustment" will be provided in the Standard

Due to the fact that the trading prices for Emissions Credits and EPCs are not publically reported, little is known about the prices paid on the market, however, it is generally accepted that the prices generally paid are more discounted than other compliance options.

79 Teresa Meadows \& Tony Crossman, "A Tale of Two Provinces: Imposing Greenhouse Gas Emissions Constraints Through Law and Policy in Alberta and British Columbia" (2010) 47:2 Alta L Rev 421 at 452 .

Ibid at 453 .

Hansard, 28 May 2008, supra note 50.

Justin Giovannetti, "Alberta to Double Carbon Tax by 2017, Strengthen Emissions Reduction Targets," The Globe and Mail (25 June 2015), online: <www.theglobeandmail.com/report-on-business/industrynews/energy-and-resources/alberta-to-double-carbon-tax-by-2017/article25109876/>. SGER, supra note 18, s 4(3).

Ibid, s $8(2)$. The price of the carbon levy is set by ministerial order as per this section. Ibid, s 6(1).

Ibid. 
for Completing Greenhouse Gas Compliance Reports. ${ }^{87}$ This definition has not yet been publicized.

There are not many further indications in the legislation which explain how the new treatment of cogeneration will operate although it seems clear that the new concept of CCA is separate and distinct from the EPC concept where cogeneration was previously fit into the regime. The 2015 SGER Amendments include a new formula for calculating the maximum amount of EPCs the director may issue in a given year to a facility which specifies that the director must subtract the facility's CCA for that year from the number of EPCs granted. ${ }^{88}$ While the rules with respect to CCAs have not been fleshed out, one key distinction between a CCA and an EPC appears to be that a CCA would only be able to be used in the year that it is generated, and would not be able to be "banked" for future years by the facility. Further, there is no express mechanism to trade CCAs under the new SGER. ${ }^{89}$

Notable provisions that were not changed by the 2015 SGER Amendments include the scope of coverage of the SGER. Despite criticisms in this regard, the SGER still only covers facilities emitting 100,000 tonnes per year, leaving approximately 50 percent of Alberta's total emissions untouched by regulation..$^{90}$

\section{B. Climate Change Advisory Panel}

In the summer of 2015 the Climate Change Advisory Panel (the Panel) was formed. ${ }^{91}$ The Panel was tasked with providing the Government of Alberta with advice to inform the development of a comprehensive climate change strategy. ${ }^{92}$ The Panel was chaired by Dr. Andrew Leach, an economist at the University of Alberta. ${ }^{93}$

\section{Climate Leadership Report to Minister}

The impact of the Paris Climate Change Conference (the COP21) on Alberta's push towards climate change legislation reform is apparent, both in the timing of the release of the Panel's Climate Leadership Report to Minister (the Climate Leadership Report), which was announced just prior to COP21, and in the express language of the Climate Leadership Report, which places the need for reform in the context of global pressure to "transition to a carbon-constrained world." $" 94$ The key features of the Climate Leadership Report are outlined below.

Ibid, s 1(d.1).

Ibid, s 9(1.1).

Bankes, supra note 74 .

SGER, supra note 18 , s 2 .

Government of Alberta, Climate Leadership, "What We Heard" (2015), online: <www.alberta.ca/ climate-leadership-discussion.cfm>.

Ibid. The Panel implemented a process to engage with the public, which included public open houses, an online survey, technical engagement sessions, aboriginal engagement sessions, a submission library, and a discussion document which lay the foundation for the climate change discussions.

93 The appointed members of the Panel were Dr. Andrew Leach, who acted as Chair of the Panel, Linda Coady, Gordon Lambert, Stephanie Cairns, and Angela Adams. Discussion Document, supra note 62 at 1 .

$94 \quad$ Andrew Leach et al, Climate Leadership Report to Minister (Edmonton: Government of Alberta, 2015) at 22, online: <www.alberta.ca/documents/climate/climate-leadership-report-to-minister.pdf $>$ [Climate Leadership Report]. 


\section{CARBON PRICING}

The recommended policy package presented by the Panel was centred around carbon pricing. ${ }^{95}$ The proposed carbon pricing model is much broader in scope than the current SGER coverage and would create two separate regimes: one for large industrial facilities which would keep the current 100,000 tonne per year emissions threshold, ${ }^{96}$ and another for end-use emissions which applies broadly across the entire economy. ${ }^{97}$

A $\$ 30$ per tonne carbon price for both large industrial emitters and end-use emitters by 2018 was proposed to be adjusted over time in real terms (inflation plus 2 percent), "as long as similar prices exist in peer and competitor jurisdictions." 98 It was recommended that revenues from carbon pricing (which could reach approximately $\$ 3$ billion by 2018 and over $\$ 5$ billion by 2030 if the program is followed) be used for defined purposes including, among other things, to offset impacts on low- and middle-income households by providing them with biannual consumer rebates and to provide fiscal capacity for other government priorities, including infrastructure. ${ }^{99}$

\section{CARBON PRICING AND COMPLEMENTARY POLICIES: ELECTRICITY}

The primary recommendations made by the Panel that impact the electricity sector are the recommendation to phase out coal-fired power in Alberta by 2030, to be replaced with renewable power, ${ }^{100}$ and to adopt a clean power call to increase capacity for renewable generation. ${ }^{101}$ It was recommended that at least 50 to 75 percent of generating capacity be replaced with renewable power, increasing the overall share of renewables in Alberta's power mix to 30 percent. $^{102}$

The Climate Leadership Report called for the adoption of a clean power call mechanism whereby the government would commit to an annual schedule of financing availability. The government would request proposals from project proponents on an annual basis and would purchase the "renewable energy attributes of the power" 103 in the form of renewable energy certificates (RECs). ${ }^{104}$ It was proposed that a facility built under this program would still sell power at market prices into the Alberta wholesale electricity market and would not be eligible for incremental revenues from the sale of offsets or RECs in other jurisdictions and would not receive output-based allocations in return for electricity. ${ }^{105}$

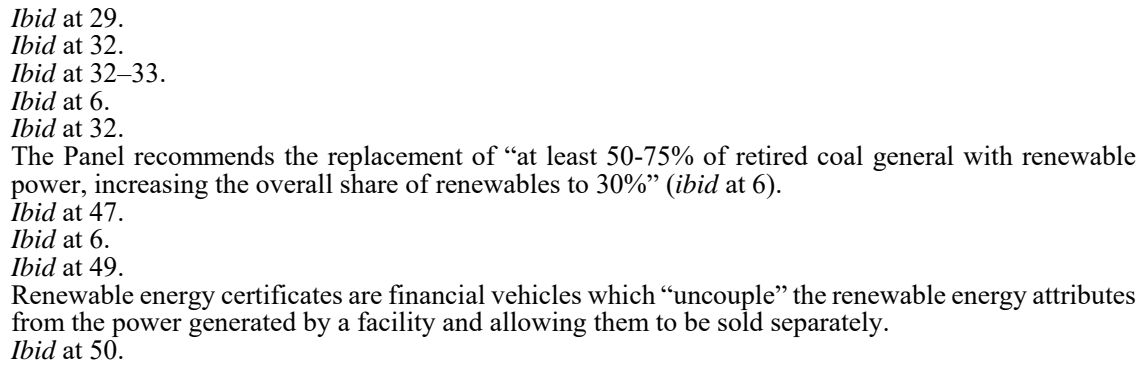


The Panel expressly rejected the idea that the province should adopt a feed-in tariff or a long-term government power purchase agreement arrangement to support project financing by small producers as has been used in other jurisdictions (in particular Ontario which will be discussed further in Part IX). Instead, the Panel recommended that Alberta's merchant market remain, with support for renewables in the form of government-purchased RECs.

\section{CARBON PRICING AND COMPLEMENTARY} POLICIES: OIL AND GAS

With respect to oil and gas, the Panel recommended an integrated policy approach which would include the carbon pricing regime for end-use emissions and oil and gas related emissions from large final emitters and a separate targeted approach for methane emission reductions. $^{106}$

With respect to the oil sands, the Panel recommended that the government allocate emissions permits "reflecting top quartile performance in in situ and mined production of bitumen, as well as establishing a parallel good-as-best gas standard for electricity which would apply to net sales from cogeneration facilities." 107 The effect of this is that facilities would be compared against their peers rather than to their own performance. ${ }^{108}$

With respect to upgrading and refining, the Panel recommended that the carbon pricing architecture be applied to upgrading and refining with output-based allocations defined according to the Solomon Complexity-Weighted Barrel. ${ }^{109}$ The Panel recommended that conventional oil and gas processing facilities be allowed to opt-in to the large final emitters treatment. $^{110}$

\section{COGENERATION}

The Panel directly addressed cogeneration in its report. Under the Panel's proposed policy architecture, the combined production of two products would, when combined with the output-based allocation for each product, lead to an emissions allocation for the facility as a whole. The Panel explained that "[r]ather than an explicit credit, having emissions credits allocated on an output basis implicitly rewards lower intensity production of both products simultaneously and that reward will be anchored in the carbon price."111 According to the

Ibid at 60 .

Ibid at 61 [emphasis in original].

The Panel expressly rejected the submission that adjustments should be made to recognize differences in reservoir characteristics. This has been advanced by some on the basis that a comparison of facilities is difficult because of differences between facilities that affect emissions output and that the system proposed by the Panel "would penalize geology rather than reward technology" (ibid). The Panel rejected this suggestion on the basis that a facility-based allocation would "effectively [subsidize] higher-emissions output" (ibid).

Ibid. This approach is used in the European Union and in California and is a way of awarding emissions permits to refineries and upgraders using a different metric than a per-barrel allocation.

Ibid. The Panel also recommended that reductions to methane could be achieved by implementing new regulatory measures for methane management in design and operation of new facilities and for leak detection and repair in all facilities and by implementing "A Time-Limited Multi-Stakeholder Collaboration for Equipment Upgrades of Pneumatic Controllers, Pneumatic Pumps and other Sources of Vented Emission in Legacy (Existing) Facilities" (ibid at 64). Ibid at 39. 
Panel, this "equalizes the treatment of cogeneration with that of combined-cycle gas." 112 As discussed above, the 2015 Amendments to the SGER introduced a new concept of "CCAs" for cogeneration. The 2015 Amendments did not clearly set out exactly how the CCAs would function under the SGER, however, there does not appear to be any similarity between these new CCAs and the Panel's recommendations.

\section{AnNouncement of Alberta Climate LeAdership Plan}

On 22 November 2015, the Alberta government announced its Climate Leadership Plan and released to the public the Climate Leadership Report commissioned by the Panel. ${ }^{113}$ The announcement stated the government's intention to implement some parts of the proposed changes from the Climate Leadership Report. With respect to electricity and renewables, the government announced that it "will phase out all pollution created by burning coal and transition to more renewable energy and natural gas generation by $2030, " 114$ that "[t]wothirds of coal-generated electricity will be replaced by renewables — primarily wind power - while natural gas generation will continue to provide firm base load reliability" 115 and that "[r]enewable energy sources will comprise up to 30 per cent of Alberta's electricity production by $2030 . " 116$

With respect to carbon pricing, the government announced that Alberta will phase in carbon pricing by calling for a $\$ 20$ per tonne economy-wide carbon price starting in January 2017 and moving to a $\$ 30$ per tonne economy-wide price in January $2018 .{ }^{117}$ The government also announced that an overall oil sands emission limit of 100 megatonnes will be set, with provisions for new upgrading and cogeneration. ${ }^{118}$ The government also stated that Alberta will implement a methane reduction strategy to reduce emissions by 45 percent from 2014 levels by $2025 .{ }^{119}$ The government also announced that the carbon pricing model will be revenue neutral and that all of the proceeds from carbon pricing will be reinvested in Alberta. ${ }^{120}$

\section{2015 United Nations Climate Change Conference}

Just after the announcement of the Climate Leadership Plan, in December 2015, Canada sent delegates to the United Nations Climate Change Conference (COP21) in Paris to negotiate an agreement on the mitigation of climate change (the Paris Agreement). ${ }^{12}$

113 Government of Alberta "Climate Leadership Plan Will Protect Albertans' Health, Environment and Economy" (22 November 2015), online: <www.alberta.ca/release.cfm?xID=38885E74F7B63-A62DD1D2-E7BCF6A98D616C09>.

Ibid.

Ibid.

Ibid.

Ibid.

Ibid.

Ibid.

Ibid.

Michael Smith, "Canada Sent 383 People to the UN Climate Conference, More than Australia, the U.K. and U.S. Together," National Post (9 December 2015), online: < news.nationalpost.com/news/canada/ canadian-politics/smyth-canada-sent-383-people-to-the-u-n-climate-conference-more-than-australia-the$\mathrm{u}-\mathrm{k}$-and-u-s-together>. 
The COP21, among other things, affirmed the goal of limiting global temperature increase well below 2 degrees Celsius, while urging efforts to limit the increase to 1.5 degrees, and established "binding commitments by all parties to make "nationally determined contributions' (NDCs), and to pursue domestic measures aimed at achieving them." 122

Signatories to the Paris Agreement will have an obligation to "prepare, communicate and maintain" 123 successive NDCs which are the dominant means through which the long-term goals will be achieved. In terms of mitigation, the Paris Agreement stipulates two long-term emissions goals: first, reaching a peak of emissions as soon as possible, then a goal of "net greenhouse gas neutrality." 124 The meaning of "net greenhouse gas neutrality" was not defined or explained but some experts have suggested that the likely meaning of this phrase is that the same amount of emissions generated must be removed to leave a net emissions output of zero. $^{125}$

While the federal government participated in COP21 with strong support from the provinces, it is still unclear what form Canada's NDC under the Paris Agreement will take. ${ }^{126}$ Canada, among 193 states, signed the Paris Agreement on 22 April 2016 and Prime Minister Justin Trudeau announced that Canada will ratify the agreement later this year. ${ }^{127}$

\section{DeVelopments After Paris}

After Paris, the Notley government began slowly rolling out the details of what the new climate change regime will look like. Some of the key announcements included the creation of the Alberta Climate Change Office ${ }^{128}$ and the delegation of the design, management, and operation of the renewables program to the Alberta Electric System Operator (the AESO). The AESO has announced that it will launch the first Renewable Electricity Program competition in late 2016 with project in-service dates in 2019. On 5 May 2016, the AESO published an update to stakeholders stating that the definition of "renewable" is anticipated to align with the definition used by Natural Resource Canada, ${ }^{129}$ that the procurement is

Center for Climate and Energy Solutions, "Outcomes of the U.N. Climate Change Conference in Paris" (12 December 2015), online: <www.c2es.org/docUploads/cop-21-paris-summary-02-2016-final.pdf>. Ibid at 3 .

Ibid.

"COP21: Experts Discuss “Greenhouse Gas Emissions Neutrality” Carbon Brief (11 December 2015), online: <www.carbonbrief.org/cop21-experts-discuss-greenhouse-gas-emissions-neutrality>.

126 Government of Canada, "Canada Plays Instrumental Role in Reaching Historic Climate Agreement" (12 December 2015), online: <news.gc.ca/web/article-en.do?nid=1024639>. See Canada's national statement at the COP21 here: Prime Minister of Canada, "Canada's National Statement at COP21" (30 November 2016), online: <pm.gc.ca/eng/news/2015/11/30/canadas-national-statement-cop21>.

127 Peter Edwards, Edith Lederer \& Cara Anna, “'Canada's Efforts Will Not Cease,' Trudeau Says at Landmark Climate Deal Meet," The Toronto Star (22 April 2016), online: <https://www.thestar.com/ news/canada/2016/04/22/trudeau-in-first-wave-of-world-leaders-to-sign-paris-climate-accord.html> .

128 See Government of Alberta, News Release, "Alberta's New Cabinet Focused on Jobs, Economic Growth and Diversification" (2 February 2016) online: $<$ www.alberta.ca/release.cfm?xID=401665F280A2ACD8C-A5B9-969CD7988C8EB46E > The mandate of the Climate Change Office is to "ensure effective coordination of all aspects of the implementation" of the Climate Leadership Plan. Few further details with respect to how the Climate Change Office will function were announced (ibid). Michael G Massicotte \& Leanne Desbarats, "Notley Government Creates Alberta Climate Change Office" ( 9 February 2016), The Resource: BLG Energy Law Blog (blog), online: <blog.blg.com/energy/Lists/ Posts/Post.aspx?ID $=430>$.

129 Natural Resources Canada defines "renewable" as "energy obtained from natural resources that can be naturally replenished or renewed within a human lifespan, that is, the resource is a sustainable source of energy. Some natural resources, such as moving water, wind and sunshine, are not at risk of depletion from their use for energy production. Biomass, however, is a renewable resource only if its rate of 
anticipated to be revenue neutral, that facilities can expect to be in service in 2019 and that "[i]t is anticipated that the existing transmission system will be leveraged." 130 All of these proposals are subject to government approval, and more details about the design of the program have yet to be finalized.

In the 8 March 2016 Speech from the Throne the government announced that it will introduce the Climate Leadership Implementation Act this session. ${ }^{131}$ Notably, this legislation was not a recommendation of the Panel and indicates another move away from the Panel's recommendations. Bill 20, the Climate Leadership Act, was introduced on 24 May 2016 and amends the Alberta Corporate Tax Act, the Alberta Personal Income Tax Act, and the Climate Change and Emissions Management Act. ${ }^{132}$ The new legislation sets Alberta's carbon levy and carbon levy rebate, establishes that revenue from the carbon levy must be invested in actions that address climate change, and establishes Energy Efficiency Alberta, a new agency that will "develop and deliver provincial-scale energy efficiency and small scale renewable programs and services." ${ }^{~} 33$ The amendments to the Corporate Tax Act reduce the small business tax rate to help small companies adjust to the price of carbon. ${ }^{134}$

The government also announced the creation of three new energy-related agencies. The Energy Diversification Advisory Committee is charged with advising the "government on additional steps Alberta can take to build a more diversified and resilient energy economy"135 and will also advise on "creating more incentives for oilsands upgrading, for more petrochemical processing and for other 'value-added' industries in Alberta, while also signalling it is open to various methods to 'enhance the economics' of those projects." 136 Energy Efficiency Alberta will "help families, businesses and entire communities reduce both their energy costs and their greenhouse gas emissions." 137 The announced Oil Sands Advisory Group will ensure that measures taken to implement the cap, land-use issues in the region, and the use of the Fund revenue are "effective and widely supported" in industry. ${ }^{138}$

consumption does not exceed its rate of regeneration" (Natural Resources Canada, "About Renewable Energy" (29 June 2016), online: <www.nrcan.gc.ca/energy/renewable-electricity/7295\#what>).

Alberta Electric System Operator, "Renewable Electricity Program Update to Stakeholders" (5 May 2016), online: <www.aeso.ca/assets/Uploads/Combined-REP-next-steps-and-questionnaire-summary. pdfs.

Government of Alberta, "Speech from the Throne: March 8, 2016" (8 March 2016), online: <www. alberta.ca/release.cfm?xID=403546D4963FB-F9BB-36E7-51711A0D395EC671>["2016 Speech from the Throne"].

Alberta, Legislative Assembly, Hansard, 29th Leg, 2nd Sess (24 May 2016) at 1095; Bill 20, Climate Leadership Act, 2nd Sess, 29th Leg, Alberta, 2016, cl 3 (assented to 13 June 2016, with exceptions) SA 2016, c-16.9.

Government of Alberta, "Climate Leadership Plan to Reduce Carbon Pollution Moves Alberta Forward" (24 May 2016), online: $<$ www.alberta.ca/release.cfm?xID=41806ECB4660F-0515-399B-BEDD7F003 DDFEDFF>.

Ibid (effective 11 January 2017, the rate will be lowered from 3 percent to 2 percent).

"2016 Speech from the Throne," supra note 131.

Geoffrey Morgan, "NDP Pledges Adding Value in Oil and Gas," Calgary Herald (9 March 2016), online: <www.pressreader.com/canada/calgary-herald/20160309/281878707471715>.

"2016 Speech from the Throne," supra note 131.

Ibid. 


\section{A. Federal INITIATIVES}

The federal government announced that it is developing a national climate change plan which will consist primarily of sector-specific emission reduction targets. ${ }^{139}$

On 3 March 2016, the results of a meeting between the federal government and the provincial governments to discuss climate change were released. ${ }^{140}$ The Vancouver Declaration on Clean Growth and Climate Change (the Vancouver Declaration) provides little detail on how emissions reductions will be achieved in Canada, but does set out key objectives agreed to by the provinces and federal government, including that national carbon pricing will be a feature of a national plan. ${ }^{141}$ The Vancouver Declaration is more of an agreement to agree in the future than a road map for reform, and provides that the First Ministers are to direct reports and provide recommendations based on those reports by October 2016. ${ }^{142}$ There is little detail on what form the federal regime will assume or how it will relate to provincial initiatives.

On 10 March 2016, the federal government, in conjunction with the United States Environmental Protection Agency, announced a number of joint initiatives with respect to climate and energy including a vow to cooperate to "implement the historic Paris Agreement." ${ }^{143}$ Key aspects of the announcement include a commitment to collaborate on "developing regulations for methane emissions from existing oil and gas sources" and to "[f]acilitate the integration of renewables on interconnected grids." 144

On 12 February 2016, Canada, Mexico, and the United States signed a Memorandum of Understanding on Climate Change and Energy Collaboration which would signal further international initiatives to coordinate efforts on climate change. ${ }^{145}$

On 22 March 2016, the federal government announced its budget for $2016 .{ }^{146}$ Climate change initiatives were a large part of the announcement and key features of the budget include, among other things, the announcement of various funding. ${ }^{147}$ The government explained that the Low Carbon Economy Fund will allocate resources "towards those projects that yield the greatest absolute greenhouse gas reductions for the lowest cost per tonne." $" 148$

John Paul Tasker, "Federal Government Should Cool Its Jets with New Climate Targets, Ontario and B.C. Premiers Say," CBC News (5 March 2016), online: <www.cbc.ca/news/politics/federalgovernment-climate-targets-1.3477171>.

Ibid.

Canadian Intergovernmental Conference Secretariat, "First Ministers' Meeting: Vancouver Declaration on Clean Growth and Climate Change" (Vancouver: CICS, 3 March 2016).

Ibid.

United States, The White House Office of the Press Secretary, "U.S.-Canada Joint Statement on Climate, Energy and Arctic Leadership," (10 March 2016), online: The White House <www.whitehouse.gov/thepress-office/2016/03/10/us-canada-joint-statement-climate-energy-and-arctic-leadership>.

Ibid.

North American Cooperation on Energy Information, online: <www.nacei.org/en/>.

Government of Canada, Budget 2016: Growing the Middle Class (Ottawa: Department of Finance, 22 March 2016), online: <www.budget.gc.ca/2016/docs/plan/budget2016-en.pdf $>$.

Ibid at $150-51,155-56$.

Ibid at 157 . 


\section{What Will The FUture Regime LoOK Like?}

It remains unclear as to whether all or part of the Panel's recommendations will be adopted. As it stands there are outstanding questions about the implementation of the regime.

\section{A. What Legislation Will Govern?}

The Climate Leadership Report proposes a new Carbon Competiveness Regulation to replace the SGER in 2018. ${ }^{149}$ On 24 June 2015, the government announced that the SGER would be extended until at least the end of $2017 .{ }^{150}$ It is unclear whether the SGER will be further extended after its expiry or whether it will be replaced at that time by the Carbon Competitiveness Regulation, or something similar, as proposed in the Climate Leadership Report. Bill 20, the proposed Climate Leadership Implementation Act, exempts specified gas emitters from the carbon levy so it appears that it is the government's intention to have two regimes, keeping the SGER for large industrial facilities and adding the end-use carbon levy via this new piece of legislation, at least for the time being. However, whether the regimes will be merged or revised prior to, or on, the expiry of the SGER in December 2017 is not clear. Many of the Panel's recommendations relate to the treatment of large industrial emitters, and no details about whether or when the government will adopt recommendations such as industry performance standards or price collars have been announced.

\section{B. Will the Regime EXtend Beyond the Panel's Recommendations to Meet the Paris Commitments?}

While the provincial government expressed strong support for Canada's involvement at COP21, even if all of the Panel's recommendations are implemented, Alberta will still not meet the standards agreed to at COP21. The Panel's recommendations would result in a decrease in emissions from current trends by approximately 20 megatonnes by 2020 , and approximately 50 megatonnes by 2030 . This would roughly stabilize emissions, by 2030 , slightly above current levels at approximately 270 megatonnes. ${ }^{151}$ While these new policies will meaningfully contribute to emissions reductions greater than what they may otherwise have been, they will not, on their own, be sufficient to meet the Paris targets. If the provincial government wishes to do so, further and more aggressive steps in furtherance of emissions reductions will need to be in Alberta's future.

\section{How Will the Proposed Federal Initiatives Interact With the Provincial Regime?}

It is unclear whether Canada will set targets and leave compliance to the provinces or whether the federal government will handle both. One potentially controversial issue will be what should be done with the revenue derived from a federal carbon pricing regime. Premier Notley has said that Alberta will support a nationwide tax on carbon so long as all revenues

149 Climate Leadership Report, supra note 94 at 31.

150 Neil McCrank \& Alan L Ross, "Temperature Check: Alberta Makes Big Move on Carbon Emissions," The Financial Post (25 June 2015), online: < business.financialpost.com/fp-comment/temperature-checkalberta-makes-big-move-on-carbon-emissions $>$.

151 Climate Leadership Report, supra note 94 at 10. 
stay in the province where they were raised. ${ }^{152}$ However, if carbon pricing is not harmonized across regions, it runs the risk of putting certain areas or businesses at a competitive disadvantage. Uncertainty in relation to the constitutional jurisdiction over natural resources and over climate change initiatives has underscored conversations about climate change in this country since the Kyoto Protocol, and while there has yet to be a constitutional challenge to any provincial or federal climate change legislation, the federal regime could be grounds for a jurisdictional challenge if tensions between the provinces and the federal government begin to mount.

\section{WILL THERE BE INTERJURISDICTIONAL OFFSET AND CARBON TRADING?}

The SGER leaves open the possibility for interjurisdictional offset and carbon trading. While this has not yet occurred, as other jurisdictions develop similar programs and as the SGER continues to evolve, such practices may become commonplace. This too could create issues leading to a jurisdictional battle in the future. For example, if the federal government takes issue with interprovincial trading regimes, it could invoke federal paramountcy rules to trump such a program. While Quebec and California have had some success with the Western Climate Initiative, the "made in Alberta" regulatory model is arguably not compatible with any existing interjurisdictional carbon markets and successful integration may require further reforms to Alberta's regulatory model.

\section{E. Will THE CCEMC CONTINUE TO Operate AS AN ARM's LENGTH CORPORATION?}

Alberta has collected $\$ 425.5$ million since it began charging the carbon levy in 2009 . To date, $\$ 350$ million has been spent by the CCEMC on projects that aim to reduce GHG emissions. ${ }^{153}$ The amounts contributed to the Fund will increase under the Climate Leadership Plan, with the corresponding increased price of Fund Credits. This may further politicize the use of the Fund revenues and questions as to whether an arm's length corporation is the proper body to manage this money may become more prevalent. Further, entrusting this money to a private corporation may also lead to issues as Alberta considers further integration and cooperation with other markets.

The Panel recommends a "re-design" of the CCEMC or the creation of a successor corporation "with a portfolio driven funding approach allowing it to invest in riskier projects." 154 The Panel stated: "[t]here is a case to be made that funding for risky technologies, which would normally be out of scope for a government, needs to be centrestage." ${ }^{\prime 155}$ Whether Albertans will be comfortable with the CCEMC handling the significant

CBC News, "Premier Rachel Notley Wants Federal Carbon-Tax Revenues to Stay in Alberta," $C B C$ News (1 October 2015), online: <www.cbc.ca/news/canada/edmonton/premier-rachel-notley-wantsfederal-carbon-tax-revenues-to-stay-in-alberta-1.3253348>.

153 Alberta Environment and Parks, "Investing in Science, Technology and Innovation" (Edmonton: 8 January 2016), online: <aep.alberta.ca/climate-change/programs-and-services/investing-in-sciencetechnology-and-innovation.aspx>.

$154 \quad$ Climate Leadership Report, supra note 94 at 81. 
Fund revenues and whether the public will have an appetite for "risky" investments as recommended by the Panel remains to be seen.

\section{F. What Will the AESO's Clean Power Entall?}

The design and details of the clean power call will be extremely important in achieving the government's renewable targets. If the program is not developed in a way that meaningfully incents renewable generation, the government's stated goals will not be achieved. The Panel provided very specific recommendations with respect to how the clean power call should operate, including that:

(1) awards should be technology-neutral, giving no preference to any specific type of renewable;

(2) a premium should be paid to those that partner with rural, First Nations, and Metis communities;

(3) renewable facilities would not be eligible for incremental revenues from the sale of offsets or RECs in other jurisdictions and would not receive output-based allocations in return for electricity;

(4) participants would be prequalified to ensure that they can deliver on projects and that they provide performance security to protect the province if they do not deliver; and

(5) any support from the Alberta government should have a collar to limit the government exposure; a cap of $\$ 35$ per $\mathrm{MWh}$ was suggested with a further suggestion that $\$ 25-35$ per MWh would initially be required to support renewable power generation. ${ }^{156}$

It is unclear whether the AESO will adopt any or all of the Panel's recommendations. One key issue will be whether participants will need to be pre-qualified to participate. It is likely that some sort of evidence of credit worthiness will be required but extensive prequalifications will limit the number of participants. One option could be to only let people with projects already approved by the Alberta Utilities Commission participate, however this would likely result in a huge surge of approvals that would need to be handled by the Alberta Utilities Commission. The AESO has indicated that a report on the AESO's proposed plan will be submitted to the government at the end of May 2016 with a plan expected to be finalized in the third quarter of $2016 .{ }^{157}$

The Canadian Press, "Alberta Power Grid Regulator Finalizing Plan to Boost Renewable Energy Investment," CBC News (10 May 2016), online:<www.cbc.ca/news/canada/calgary/alberta-renewablesenergy-plan-1.3575919>. 


\section{CRITIQUE ON THE EFFECTIVENESS OF THE \\ Provincial Regulatory FrameWORK AS AN InCENTIVe For THE EMERgenCE Of ReneWABLe PoWer}

One of the major uncertainties in the implementation of the Climate Leadership Plan is whether the proposed framework will adequately incent renewable power generation in the context of Alberta's deregulated electricity market.

Alberta has a unique regulatory model whereby long-term contracts for independent power producers are not provided. Rather, electricity must be "exchanged through the Alberta power pool" "158 which functions as a spot market, establishing an hourly pool price to match demand and supply. While this system has historically been successful in increasing investment in electricity generating projects in the province, it is somewhat incompatible with incentivising smaller scale generators to invest in projects due to the large market risk in building a power plant. In practice, this feature of Alberta's deregulated electricity system has not created market conditions that encourage small producers to invest. ${ }^{159}$

One reason for this is that new projects are not able to provide sufficient returns and debt coverage to lenders due to the merchant market structure and lenders are not provided with sufficient long-term revenue certainty to incentivize investment. ${ }^{160}$ One solution to this problem is by providing long-term power purchase agreements to renewable project developers in an effort to provide some long-term certainty to these projects and attract debt financing.

Another problem is that renewable energy sources currently trade at a discount in Alberta's power market and so prices need to be very high in order to provide the appropriate conditions to encourage the construction of new projects. ${ }^{161}$

The Panel's proposed structure is promising, but it may not afford sufficient price certainty in order to incentivize investment on the large scale required. The province may need to provide more revenue certainty to permit the long-term financing of these projects, including for example, providing long-term power purchase agreements.

The Panel addressed this issue directly in the Climate Leadership Report, pointing out that recent wind development in the province has succeeded without long-term contracts and that in its view, long-term contracts for the sale of Offset Credits, rather than power purchase agreements, may be sufficient to provide market certainty. ${ }^{162}$ The Panel further rejected the idea that a feed-in tariff program, along the lines of the one used in Ontario, would be

KPMG, "Alberta's Future Energy Mix: Exploring the Potential for Renewables" (February 2014) at 8, online: <www.kpmg.com/Ca/en/IssuesAndInsights/ArticlesPublications/Documents/Kpmg-Issue3Alberta-Reduced-Size.pdf $>$. Ibid.

Ibid at 14 .

For example, according to the Climate Leadership Report, supra note 94 at 56, wind currently sells at an average pool price that is at a discount of 30-40 percent to what coal and natural gas plants sell at. Because of this, the Climate Leadership Report estimates that prices would "still likely require prices well-above $\$ 100 / \mathrm{MWh}$ to guarantee construction of new projects" and as such major incremental financial support will be required to encourage development (ibid). 
appropriate, stating that such a system "would remove the incentives provided by the merchant market to build renewable facilities which generate the highest value power, not simply the most power." 163

Another outstanding question is whether the AESO's clean power procurement process will provide any criteria to deal with such things as geographic wind variations, location of load, and transmission or distribution constraints, or whether these will be left to market forces.

As it currently stands, there exists some degree of uncertainty as to whether these aggressive renewables targets are realistic and there is the potential that a future government will change these standards. This uncertainty creates risk for renewable project developers who need to contemplate the economics of large-scale projects on a long-term time basis.

\section{WINNERS AND LOSERS: INDUSTRY IMPLICATIONS}

All actors in Alberta's economy will be impacted by the Climate Leadership Plan. This part of the article focuses on industry winners and losers in the electricity and oil and gas sectors.

\section{A. Renewable Power Generators}

Renewable power generators will likely be the clearest winners in the new regime. With the ambitious target of replacing two thirds of coal-generated electricity with renewables by 2030, representing 30 percent of Alberta's electricity production, significant investment, likely supported by government, will be required. In 2015, the combination of wind (5 percent), biomass ( 3 percent), and hydro-electric power ( 2 percent) only amounted to 10 percent of generation in the province. ${ }^{164}$

There are numerous outstanding questions with respect to how these ambitious targets will be reached and it is unclear how the government will sufficiently incentivize renewable generation. Key issues with respect to renewable projects include: (1) system access, reliability, and grid integration; (2) renewable financing; (3) land use conflicts; and (4) regulatory process coordination. Further, each type of renewable source faces unique issues and challenges that will need to be addressed in order to build generation on the scale contemplated.

While the Panel made a "technology neutral" recommendation, suggesting that the government not make any distinction based on the type of renewable energy used in executing the clean power call, it is unclear at this point whether the government will direct the mix of renewables in the province or leave this to the market to decide. The Electric Utilities Act expressly provides that neither the market nor the structure of the Alberta electric industry is to distort or unfairly advantage any market participant and that "all persons wishing to exchange electric energy through the power pool may do so on non-

164 Alberta Energy, "Electricity Statistics" (Edmonton: 2016), online: <www.energy.alberta.ca/electricity/ 682.asp>. 
discriminatory terms." ${ }^{\prime 65}$ However, some structural changes to the electric system may be needed in order to accommodate the introduction of renewables on the scale required.

\section{WIND}

While wind power will likely constitute the bulk of the renewable energy generation required under the Climate Leadership Plan, further significant investment will be required to meet this demand. Further, there are unique issues with wind power. Wind farms take up a large amount of geographic space and require power to be gathered over large distances. Wind power also has a low capacity. Often, wind generation creates unstable power levels, especially when concentrated in a geographic area - when wind generation is weak or fails, generation must be quickly dispatched from other sources to fulfill demand. ${ }^{166}$ Wind must be backed up due to the intermittent nature of power generation which will likely be managed by the use of natural gas. This creates a redundancy in the system since more gas generators would need to be built to support wind farms. Wind also currently sells at a discount in the Alberta power market, with the average price being at a discount of 30 to 40 percent relative to coal and natural gas. ${ }^{167}$

As stated in the Climate Leadership Report prices would need to be "well-above $\$ 100 /$ MWh to guarantee construction of new projects." 168 Accordingly, financial support will be required to provide the market conditions necessary to promote development. Further, as discussed below in the context of Ontario's experience with renewables, wind has not been a popular option in other jurisdictions. Whether the "anti-wind" movement that has been prevalent in Ontario will similarly impact the growth of wind power in Alberta remains to be seen.

Alberta has a very stable electricity supply, and the system is structured in a way that large reserves are available to mitigate disturbances in the system. However, because of the intermittent nature of wind power, more reserves will likely need to be procured in order to maintain the same level of stability that Albertans have been accustomed to. As it now stands, the cost of procuring reserves is not passed on to generators, however, possibly a redesigned structure could provide for generators to pay for the reserves required for their potential generation source. This may entail wind generators paying more for reserves than more stable generation sources, for example solar. While a redesign of the system to account for different treatment of reserve costs may make sense from an economic perspective, it would face challenges. Such a structure would run contrary to the Panel's technology-neutral recommendation and to the requirements in the Electric Utilities Act not to favour certain industry participants over others. ${ }^{169}$

SA 2003, c E-5.1, s 5(b) [EUA].

Alberta Electric System Operator, "2014 Annual Market Statistics," at 21, online: <https://www.aeso. ca/download/listedfiles/2014-Annual-Market-Stats-WEB.pdf $>$.

Climate Leadership Report, supra note 94 at 56.

Ibid.

Section 5 of the EUA, supra note 165 provides:

The purposes of this Act are

(b) to provide for a competitive power pool so that an efficient market for electricity based on fair and open competition can develop, where all persons wishing to exchange electric energy through the power pool may do so on non-discriminatory terms and may make financial arrangements to manage financial risk associated with the pool price; 


\section{SOLAR}

Solar power is not currently a major source of power generation in Alberta. In 2014, solar power was not listed on Alberta Energy's list of generation sources. ${ }^{170}$ However, the Climate Leadership Report is optimistic about more widespread use of solar electricity in the province, noting that "Alberta has some of the best solar resources in Canada."171 The Chief Executive Officer of Capital Power Corp. stated that "solar power is quickly dropping in price and, with improvements in battery technology, could 'dominate' renewable power builds in Alberta closer to 2030." 172 Solar energy sources are a good source of power as they generate energy during higher price periods in the day, and if these projects are developed, they will likely receive higher pool prices in the market for this reason. ${ }^{173}$

\section{HYDRO-ELECTRIC}

Hydro-electric power is not even mentioned in the Climate Leadership Report. However, Canadian Utilities stated that it is planning large-scale hydro projects over the longer term, including one on the Athabasca River near Fort McMurray. ${ }^{174}$ Even if ultimately feasible, hydro-electric is not an immediate solution to meet the new renewables targets, as projects typically take a considerable time to be developed. ${ }^{175}$

\section{NUCLEAR}

There do not appear to be any plans to pursue nuclear power generation in the province. Further, nuclear power generation is not a natural fit for Alberta's deregulated market.

\section{GEOTHERMAL}

There are currently no geothermal electricity projects in Canada. While the Climate Leadership Plan may make the economics of geothermal energy projects more attractive, it remains to be seen whether the government will put in place the proper programs and create the appropriate incentives in order for such projects to be developed in Alberta. ${ }^{176}$

(c) to provide for rules so that an efficient market for electricity based on fair and open competition can develop in which neither the market nor the structure of the Alberta electric industry is distorted by unfair advantages of government-owned participants or any other participant.

Alberta Energy, "Electricity Statistics," supra note 164.

Climate Leadership Report, supra note 94 at 49.

Geoffrey Morgan, “Alberta Utility Firms Brace for Early Phase Out of Coal Under Notley's Climate Change Policies," The Financial Post (12 November 2015), online: < business.financialpost.com/news/ energy/alberta-utility-firms-brace-for-early-phase-out-of-coal-under-notleys-climate-change-policies?lsa=c751-7338\& lsa=c751-7338> [Morgan, "Alberta Utility Firms Brace"].

Climate Leadership Report, supra note 94 at 50.

Morgan, "Alberta Utility Firms Brace," supra note 172.

Hydroelectric Power Generation Development Inquiry, (28 February 2011), Proceeding ID No 561, online: AUC <www.energy.alberta.ca/Electricity/pdfs/HydroelectricPowerInquiry.pdf $>$.

Tyler Hamilton, "Alberta's Green Energy Future," Corporate Knights (11 June 2014), online: $<$ www.corporateknights.com/channels/climate-and-carbon/albertas-green-energy-future-14025034/>; Kyle Bakx, "Geothermal Pitched as Alberta's Next Big Energy Source," CBC News (1 July 2015), online: $<$ www.cbc.ca/news/business/geothermal-pitched-as-alberta-s-next-big-energy-source-1.3132416 ? $\mathrm{cmp}=\mathrm{rss}>$. 


\section{BiOENERGY}

Bioenergy already contributes to Alberta's energy mix, albeit on a small scale. Alberta had a Bioenergy Producer Credit Program to provide incentives to producers of a wide variety of bioenergy products, including renewable fuels and electricity from biomass, which closed in 2016. The government has not announced whether it will renew the program. That said, on 11 March 2016 Premier Notley announced that $\$ 10$ million from the Fund will be used to fund "Edmonton-based SBI BioEnergy to build a \$20 million facility that will produce a diesel-like fuel from off-grade canola." "177

\section{B. CoAl-Fired Power Plants}

Coal producers will most certainly be among the biggest losers in the new regime as coal currently represents 40 percent of the supply mix in the province and the Climate Leadership Plan requires coal-fired power plants to either cut their emissions to zero or shut down by 2030. ${ }^{178}$ While the federal government already provides for the retirement of coal-fired electricity generating units pursuant to the Reduction of Carbon Dioxide Emissions from Coal-fired Generation of Electricity Regulations, ${ }^{179}$ the provincial policy would further limit the useful life of a coal-fired unit. ${ }^{180}$

This has significant consequences for companies that have invested heavily in coal plants. For example, the Keephills 3 coal-fired power plant cost $\$ 1.6$ billion to build and only began generating electricity in 2011. Pursuant to the federal regulations, its useful life would be 2061, and accordingly, the Climate Leadership Plan would shave off 31 years of this plant's useful life.

A negotiator has been appointed to discuss possible compensation for coal power companies. ${ }^{181}$ It is unclear how compensation may be handled but some options include: (1) repayment of the costs to build the plants; (2) payment of the cost to replace the remaining utility of those assets; or (3) a payout representing what the utilities would have earned on

The Canadian Press, "Alberta Uses Cash Raised from Carbon Levy to Help Finance Green Energy Project," National Observer (10 March 2016), online: <www.nationalobserver.com/2016/03/10/news/ alberta-uses-cash-raised-carbon-levy-help-finance-green-energy-project>. Climate Leadership Report, supra note 94 at 6.

SOR/2012-167 [Carbon Dioxide Emissions Regulations].

The federal regulation provides that the end-of-useful life of a coal-fired electricity generating unit is generally 50 years. Plants built before 1975 have to be decommissioned by the year 2020, and plants built after 1975 need to be decommissioned by 2030 unless they are equipped with carbon capture and storage. For a unit commissioned on or after 1986 reaches the end-of-useful life on December 31st of the 50th year that follows its commission date (ibid, s 2(1)).

181 On 16 March 2016, the government announced that Terry Boston, an American businessman who recently retired from PJM Interconnection, will act as the province's independent "coal phase-out facilitator," tasked with developing "options to phase out emissions from coal-fired generation by 2030, as outlined in the Climate Leadership Plan" by September 2016 (Government of Alberta, News Release, "Alberta Takes Next Steps to Phase-Out Coal Pollution Under Climate Leadership Plan" (16 March 2016), online: <www.alberta.ca/release.cfm?xID=40400064C4850-E326-56B9-4ED21CDD882F3 $960>$ ). 
the assets had they continued to operate. ${ }^{182}$ One potential option would be to grant coal-fired generators preferential rights to renewable power opportunities.

The recent legislative changes have prompted a reaction from utilities. On 7 March 2016, TransCanada Corporation (TransCanada) announced that it plans to terminate its Power Purchase Agreements (PPAs) in reliance on a provision in its PPAs that allows termination based on a change in law. ${ }^{183}$ TransCanada has elected to terminate the PPAs for the Sheerness, Sundance A, and Sundance B plants, citing unprofitable market conditions and the increasing costs of carbon emissions which are forecast to continue over the remaining term of the PPAs. ${ }^{184}$ This was preceded by Enmax's decision to end its Battle River PPA with ATCO Power in December which it attributed to unprofitable market conditions. ${ }^{185}$ Capital Power announced it was terminating its PPA for the Sundance C coal-fired power plant on 25 March $2016^{186}$ and AltaGas Ltd. is reportedly also terminating its PPA with the Sundance B plant. ${ }^{187}$

In accordance with the $E U A^{188}$ when a buyer elects to terminate a PPA it is deemed to have been sold to the Balancing Pool, which assumes the role of the Buyer. ${ }^{189}$ In the event the Balancing Pool elects to terminate the PPA, it is required under the EUA to first consult with representatives of customers and the Minister of Energy. The Balancing Pool has discretion over whether to continue to buy and distribute the power itself, resell or terminate a PPA that it holds, or to terminate the agreement in its entirety by paying the owner the net book value of the plant. ${ }^{190}$

These developments have significant implications in the electricity sector. In the event that coal-fired capacity is taken offline even earlier than envisioned by the provincial and federal governments, there may not be a stable source of replacement power available. How this will impact the government's already lofty ambitions to replace, on a grand scale, coal-fired power with renewables remains to be seen. ${ }^{191}$ Given the government's announcement that compensation for coal plant owners will be made, this could impact those negotiations as

Geoffrey Morgan, "Coal-Fired Power Plants Feel the Heat of Alberta's New Carbon Tax Rules," The Financial Post (26 June 2015), online: < business.financialpost.com/news/energy/coal-fired-powerplants-feel-the-heat-of-albertas-new-carbon-tax-rules>; Tracy Johnson, "Coal Power Plant Shutdown Could Hit Alberta Taxpayers," CBC News (18 November 2015), online: <www.cbc.ca/news/business/ coal-compensation-power-alberta-1.3321467>.

TransCanada Corporation, News Release, "TransCanada to Terminate Alberta Power Purchase Arrangements" (7 March 2016), online: <www.stockhouse.com/news/press-releases/2016/03/07/trans canada-to-terminate-alberta-power-purchase-arrangements $>$.

Ibid.

185 Darcy Henton, “Enmax Terminates 'Unprofitable’ Coal-fired Electricity Contract,” Calgary Herald (18 January 2016), online: <calgaryherald.com/news/politics/enmax-terminates-unprofitable-coal-firedelectricity-contract>.

186 The Canadian Press, "Capital Power Ditches Deal to Buy Power of Sundance Coal-Fired Plant," CBC News (24 March 2016), online: <http://www.cbc.ca/news/canada/edmonton/capital-power-ditches-dealto-buy-power-of-sundance-coal-fired-plant-1.3505648>.

187 Geoffrey Morgan, "Alberta Coal Power Contracts Terminated as Natural Gas Prices Plunge," The Financial Post (7 March 2016), online: < business.financialpost.com/news/energy/transcanada-corp-toterminate-coal-power-contracts-due-to-higher-emissions-costs $>$.

EUA, supra note 165 .

Ibid, s 96.

Ibid, s 97.

The federal Carbon Dioxide Emissions Regulations, supra note 179 provides that the end of "useful life" of a coal-fired electricity generating unit is 50 years. Section 2 provides that a unit commissioned on or after 1986 reaches the end-of-useful life on December 31st of the 50th year that follows its commission date. 
well. If the Balancing Pool decides to terminate PPAs, it will also have a large impact on customers as the Balancing Pool would potentially owe significant sums of money to the power plant owners. These costs would inevitably be passed on to consumers. The government has announced that the Balancing Pool will conduct an investigation to assess and analyze the potential impacts of the termination of the PPAs. ${ }^{192}$

Further, the Power Purchase Arrangements Regulation ${ }^{193}$ provides that if a plant is decommissioned within one year of the PPA's termination, the owner of the generating unit is entitled to receive from the Balancing Pool the amount that the costs of decommissioning exceeds the amount the owner collected from customers. ${ }^{194}$ These costs are expected to be significant and are expected to be passed on to consumers. ${ }^{195}$

The government responded to TransCanada's announcement in the legislature on 10 March 2016, expressing its disapproval of the terminations. ${ }^{196}$ Premier Notley has signalled that she will fight against the terminations, stating that her government will review their legality. One argument she has already raised publically is that the change in law provisions in the PPAs are not applicable yet because there has not been a change in law. She stated, "“[r] egardless of how wide or narrow one's interpretation is of the clauses that were injected into these agreements over a decade ago, you don't get to take action on the basis of something that hasn't happened yet.",197

The PPAs are a stable source of revenue for owners and are attractive to credit agencies on this basis. The end of the PPAs may make it more difficult to attract debt financing. However, on the flip side, the end of the PPAs could also result in more forward-trading on the spot market in Alberta and could result in more accurate pricing of electricity.

\section{Natural Gas Producers}

Natural gas producers are likely winners under the Climate Leadership Plan. With coal being phased out, and the oil sands facing an emissions cap, natural gas will likely be the only hydrocarbon to benefit from the new policies. The Canadian Association of Petroleum Producers believes the coal-to-gas switch in power generation over the next 15 years will add 1.5 billion cubic feet per day to natural gas production. ${ }^{198}$ This is positive news for an industry that has struggled in light of recent low natural gas commodity pricing. However, there is a downside for natural gas producers. Some of the older, more mature natural gas

Darcy Henton, "Balancing Pool to Investigate Impact of PPA Terminations," Calgary Herald (19 March 2015), online: <calgaryherald.com/business/energy/balancing-pool-to-investigate-impact-of-ppaterminations $>$.

$193 \quad$ Alta Reg 167/2003.

194 Ibid, s 5.

195 This provision of the regulation ends in 2018 and decommissioning costs are not available after that date (ibid, s 5(4)).

196 Alberta, Legislative Assembly, Hansard, 29th Leg, 2nd Sess (10 March 2016) at 84 (Hon Premier Notley).

197 Darcy Henton, "Premier Signals a Fight is On with Utilities Over Dumping Money-Losing Contracts on Consumers," Calgary Herald (1 April 2016), online: <calgaryherald.com/storyline/premier-signals-afight-is-on-with-utilities-over-dumping-money-losing-contracts-on-consumers>.

198 Tim McMillan, "Natural Gas is the Solution, Clean and Simple," Canadian Association of Petroleum Producers (14 October 2015), online: <www.capp.ca/media/commentary/natural-gas-is-the-solutionclean-and-simple>. 
wells may need to be abandoned due to the more stringent proposed regulations with respect to methane. ${ }^{199}$

\section{OIL SANDS COMPanies}

The Climate Leadership Plan contemplates an absolute emissions cap of 100 megatonnes of GHGs from oil sands production in any year. ${ }^{200}$ The Climate Leadership Plan notes that oil sands emissions currently emit roughly 70 megatonnes per annum. ${ }^{201}$ If all of the currently approved projects proceed, it is projected that the cap will already be exceeded. ${ }^{202}$ As a result, it is unclear what will happen to already approved projects and the significant capital that has been invested in developing them. However, some, including the Notley government, have argued that the cap is good public relations for the oil sands which will assist oil sands players in their ability to market projects both nationally and internationally. ${ }^{203}$

Further, depending on the portfolio of facilities of an oil sands company, the Panel's proposal that facilities be compared against peers rather than to their own historic emissions may in fact mean that oil sands facility owners actually profit off of the new regime. Currently, the SGER provides that a facility's allocation of emissions is based on the facility's own historic emissions intensity. ${ }^{204}$ The Panel's proposed regulation would shift this so that a facility's allocation of emissions would be based on sector-wide, output-based allocations. ${ }^{205}$ As a result, a facility would be judged against its peers rather than being judged against itself.

If a facility is already emitting specified gases below industry norms, it will be able to sell offsets and turn a profit. However, compliance for other facilities may stand to be very costly. The impacts on specific companies will depend on where the performance standard is met. The Panel suggested top-quartile as a performance standard but it is unclear what will ultimately be adopted. It is also possible that the government will impose compliance price collars to avoid windfall losses and gains under the program.

\section{E. Pipeline Project Proponents}

Premier Notley has asserted that the new Climate Leadership Plan is beneficial for pipeline project proponents as a type of public relations tool in cleaning up Alberta's reputation as a "dirty" oil producer. ${ }^{206}$ This sentiment is shared by others in the industry as well. The Canadian Association of Petroleum Producers has stated that it expected that the

Yadullah Hussain, "Why the Natural Gas Industry Isn't Celebrating Alberta's Climate Policy Just Yet," The Financial Post (27 November 2015), online: <business.financialpost.com/news/energy/why-thenatural-gas-industry-isnt-celebrating-albertas-climate-policy-just-yet $>$. Government of Alberta, "Capping Oil Sands Emissions," online: <www.alberta.ca/climate-oilsandsemissions.cfm>. Ibid.

Jeff Lewis, "Watchdog Not Told of Alberta's Plan to Cap Oil Sands Emissions," The Globe and Mail (3 December 2015), online: <www.theglobeandmail.com/report-on-business/industry-news/energy-andresources/watchdog-not-told-of-albertas-plan-to-limit-oil-sands-emissions/article27589003/>. Pipelines," Calgary Herald (22 November 2015), online: <calgaryherald.com/business/energy/ewartalbertas-new-climate-plan-touted-as-a-marketing-solution-for-oilsands $>$. 
policies recommended in the Climate Leadership Plan would help " "to further enhance the reputation of our sector and improve our province's environmental credibility as we seek to expand market access nationally and internationally.",207

\section{EXPERIENCE IN OTHER JURISDICTIONS}

\section{A. Ontario}

In February 2009, six years before Premier Rachel Notley set Alberta on its path to significantly expand renewable energy projects, the Ontario government announced the introduction of the Green Energy Act, ${ }^{208}$ which had similar goals to those articulated by Premier Notley. Interestingly, when Ontario started down the road to the development of significant wind and solar generation projects, Alberta seemed well ahead of Ontario in this area. Ontario had very few wind generation projects and no sizable solar facilities. Alberta, being endowed with enviable wind resources (especially in the southwest part of the province), was looked to by some as an early example for Ontario's wind industry.

Ontario set out to incentivize the large scale development of wind, solar, biomass, and biogas powered generation when it passed the Green Energy Act. While clean energy production was one of the reasons for the government taking this initiative, much was also made of the 50,000 jobs the government promised would be created through "green manufacturing" and other activity related to the development of renewables. ${ }^{209}$ Partly through the imposition of Ontario content requirements (which were controversial and eventually scrapped when found to violate World Trade Organization regulations), ${ }^{210}$ the program did create jobs, but not in the numbers projected by the government. Moreover, the nature of the estimated 31,000 or so jobs generated by the program were largely short-term construction and manufacturing jobs — not the permanent high paying manufacturing positions government sought (along the lines of those seen historically in the auto manufacturing sector). ${ }^{211}$

\section{FEED IN TARIFF}

One of the most notable features of the Green Energy Act program was the introduction of a Feed in Tariff (also known as a FiT program). ${ }^{212}$ The Ontario FiT program follows the model that has been used in other jurisdictions (many in Europe, for instance in Germany) where it has been used extensively to encourage developers to enter the field. The essential

207

\section{Ibid.}

SO 2009, c 12, Schedule A.

Ontario, Ministry of Energy "Feed-in Tariff Program Two-Year Review: Background," online: <www. energy.gov.on.ca/en/fit-and-microfit-program/2-year-fit-review/background/ $>$.

Karen Howlett, Bertrand Marotte \& Richard Blackwell, "WTO Rules Against Ontario in Green Energy Dispute," Globe and Mail (20 November 2012), online: <www.theglobeandmail.com/report-onbusiness/industry-news/energy-and-resources/wto-rules-against-ontario-in-green-energy-dispute/ article5461941/>. The WTO decision can be found here: WTO, Canada-Measures Relating to the Feedin Tariff Program, Dispute D5426, online: <www.wto.org/english/tratop_e/dispu_e/cases_e/ds426_e. $\mathrm{htm}>$.

Ross R McKitrick, "Environmental and Economic Consequences of Ontario's Green Energy Act," Fraser Institute at 23 , online: $<$ www.fraserinstitute.org/sites/default/files/environmental-and-economicconsequences-ontarios-green-energy-act.pdf $>$.

Electricity Act, SO 1998, c 15, Schedule A, s 25.35, as amended by Green Energy Act, supra note 208. 
element of the Ontario FiT program (like many others) is the fixed price approach to paying for power supplied by renewable generators. The FiT program set prices for each of the generating sources at different levels that reflected the size of projects (amount of power generated) as well as the costs associated with the particular technologies. Solar generation saw the highest prices which were as much as 80.2 cents per kWh for early micro (very small) projects and approximately 30 cents per $\mathrm{kWh}$ for more recent larger sized commercial projects. ${ }^{213}$ Wind power projects, which receive less than solar facilities as the technology involved is less expensive, have recently been paid 12.8 cents per $\mathrm{kWh}$, a reduction from early FiT prices for wind that had been in the "teens" per $\mathrm{kWh} .{ }^{214}$

The price setting of the Ontario FiT program evolved as the relative cost of different types of projects became more predictable and as the price for the various technologies dropped with the evolution of the sector. Indeed, one of the more helpful aspects of the Ontario FiT system from the point of view of other jurisdictions seeking to incentivize wind and solar development, is that prices for power now more accurately reflect the actual cost of the technology than they did when the Ontario FiT program was first introduced.

The Ontario FiT program, while having prices set by the government, was still competitive in nature. Prospective developers, having obtained rights to land and having conducted other preliminary development activity, bid into one of several FiT program windows over time. The Ontario Power Authority (recently merged with the Independent Electricity System Operator) would then review the applications of the various bidders and decide which projects ought to have FiT Contracts offered to them. The successful bidders then had a period of time (typically in the order of three or four years) to get their project operating. As proponents often had to complete permitting, financing, construction, and commissioning in that period, the timing was often quite tight. Indeed, another lesson learned has been that renewable power project development is more time consuming than was originally thought by most. Some of the more significant sources of delay (discussed below) have related to permitting.

\section{DELAYS AND CONTROVERSY}

At the time of the advent of the Green Energy Act, there was general concern that the regulatory regime in Ontario needed to be more streamlined and consistent. "Set back" distances for wind turbines, for example, were imposed by municipalities. This resulted, over time, in the development of a patchwork quilt of differing set back distance requirements across the province. Further, there was no single regulator to coordinate the permitting processes. To address these issues, the Green Energy Act standardized set back requirements and created a one window approach to regulation (though there has been some concern about the size, quality, and effectiveness of the window). ${ }^{215}$ These are but two of several attempts to address challenges to renewable development in the province.

Independent Electricity System Operator, “Ontario’s Feed-In Tariff Backgrounder," online: $<$ fit.power authority.on.ca/program-resources/newsroom/december-16-2009-ontarios-feed-tariff-programbackgrounder>.

Ibid.

Green Energy Act, supra note 208. 
What was probably most unexpected by developers and government was the reaction to wind development across the province by "concerned citizens." The revised permitting system for large renewable (wind, solar, and biomass — not hydro-electric which had its own pre-existing permitting process) had resulted in the creation of a global permit called a Renewable Energy Approval ("REA") to replace the myriad of permits that had applied previously to such projects. ${ }^{216}$ The Green Energy Act also created an appeal process for use by anyone who thought that a particular renewable project would cause either: (1) serious harm to human health; or (2) serious and irreversible harm to the natural environment.

In order to create some certainty of process, the Environmental Protection Act ${ }^{217}$ imposed strict deadlines on hearings related to REA appeals. Appeals must be brought within 15 days of the granting of the REA. ${ }^{218}$ It is worth noting (perhaps even a lesson to be learned) that these deadlines have been adhered to in all but a few instances. The intended certainty around timing of the appeal process, while not absolute, was significant. However, what was not anticipated was the number of projects that would be subjected to REA appeals.

Solar projects have largely avoided being appealed, and the few appeals that have been initiated have been resolved or withdrawn very quickly. Wind projects, on the other hand, have not been so lucky - most (but not all) have been appealed. In fact, Ontario has the distinction of being the world centre for the "anti-wind" movement. Nowhere else is there as much attention (academic, public interest, media, concerned citizens) to the potential negative impacts of wind generated power. While there are likely many reasons for this it would seem that the success of the Green Energy Act and the number of projects being built in (what to some seemed like) a big rush probably exacerbated the troubles. Adding fuel to the fire were statements by the premier and other ministers at the time that the "not in my backyard" syndrome (NIMBY-ism) would not be allowed to interfere with renewable development, meaning that municipalities would not be able to reject wind turbines. ${ }^{219}$ Those who were literally going to be looking across their backyards at large wind turbines on neighbouring lands (meaning they would not be paid for tolerating the new landscape) reacted as one might think - they were not happy.

This brief summary is only a preliminary overview of lessons taught by the Ontario experience. However, at a minimum, it is important to note that large-scale and "sudden" development like that seen in Ontario (and, it would appear, hoped for in Alberta) can create regulatory, public perception, and other issues that are not anticipated. For this reason those who are active participants in the development process, be they with government, private developers, agencies, or public interest groups, need to expect the unexpected.

Renewable Energy Approvals under Part V.0.1 of the Act, O Reg 359/09.

RSO 1990, c E.19.

Ibid, s 142.1(2).

The Canadian Press, "New Law Will Keep NIMBY-ism From Stopping Green Projects: Ont. Premier," CBC News (10 February 2009), online: <www.cbc.ca/news/technology/new-law-will-keep-nimby-ismfrom-stopping-green-projects-ont-premier-1.805978>; Rob Ferguson, "McGuinty Vows to Stop WindFarm NIMBYs," The Toronto Star (11 February 2009), online: <www.thestar.com/news/ontario/2009/ 02/11/mcguinty_vows_to_stop_windfarm_nimbys.html $>$. 


\section{B. BRITISH COLUMBIA}

Like Alberta, British Columbia has also recently undertaken a significant overhaul of its climate action legislation. On 1 January 2016, the Greenhouse Gas Industrial Reporting and Control Act ${ }^{220}$ and its regulations, the Greenhouse Gas Emission Reporting Regulation, ${ }^{221}$ the Greenhouse Gas Emission Control Regulation, ${ }^{222}$ and the Greenhouse Gas Emission Administrative Penalties and Appeals Regulation, ${ }^{223}$ came into force, replacing British Columbia's previous cap-and-trade system and creating a new regulatory scheme that focuses on reducing the "intensity levels" of GHG emissions generated by industrial facilities (such as LNG facilities), rather than imposing hard caps on the amount of GHGs that facilities can generate. The new legislation aims to reduce GHG emissions by encouraging facility owners to use cleaner energy sources and make their operations more efficient. British Columbia is actively encouraging LNG proponents to consider using electricity derived from clean, renewable energy sources to power their facilities and production activities. The province has referred to BC Hydro's development of the Site C Clean Energy Project as a key component of its GHG reduction strategy. ${ }^{224}$

\section{NEW GREENHOUSE GAS INDUSTRIAL REPORTING AND CONTROL ACT}

The GGA was introduced amidst pledges from the British Columbia government to make British Columbia's LNG facilities the "cleanest in the world". ${ }^{225}$ The legislation seeks to balance two of the province's key objectives: (1) reducing GHG emissions; and (2) encouraging the development of LNG projects in British Columbia. In 2007, British Columbia legislated specific targets for reducing GHG emissions in the Greenhouse Gas Reduction Targets Act. ${ }^{226}$ In the GGRTA, British Columbia pledged to reduce provincial GHG emissions by 33 percent below 2007 levels by 2020 and 80 percent below 2007 levels by 2050; however, the GGRTA did not prescribe any specific means of achieving these reductions or impose any restrictions or obligations on private sector organizations to limit industrial GHG emissions. ${ }^{227}$ The new GGA has introduced specific emissions targets and reporting obligations for LNG facilities and coal-fired electricity generating facilities in British Columbia.

With respect to the LNG sector, the GGA requires LNG facilities to limit their GHGs to the equivalent of 0.16 tonnes of carbon dioxide per tonne of $L N G$ produced, which is one of the most stringent emissions benchmarks in the world for LNG facilities. ${ }^{228}$ The benchmark

SBC 2014, c 29 [GGA].

BC Reg 249/2015.

BC Reg 250/2015.

BC Reg 248/2015.

The Honourable Judith Guichon, Lieutenant Governor of British Columbia, "Speech from the Throne" (9 February 2016), online: <www.engage.gov.bc.ca/thronespeech/transcript/> ["2016 BC Speech from the Throne"]; Ian Bailey, "Christy Clark Hopes Climate Deal Means Support for Alberta Hydro Link," The Globe and Mail (3 March 2016), online: <www.theglobeandmail.com/news/british-columbia/ christy-clark-hopes-climate-deal-means-support-for-alberta-hydro-link/article29027505/>.

Government of British Columbia, News Release, "World's Cleanest LNG Legislation Comes Into Force" (18 December 2015), online: <news.gov.bc.ca/releases/2015ENV0084-002116>. SBC 2007, c 42 [GGRTA].

Ibid, s 2.

GGA, supra note 220 , ss 5-6. 
covers all emissions from a facility (including combustion, electricity generation, venting, and fugitives) from the time that natural gas enters the facility to the time that it leaves. ${ }^{229}$ Operators of LNG facilities must avoid exceeding the intensity level set out in the benchmark; otherwise, they could face fines of up to $\$ 1.5$ million and up to two years' imprisonment. $^{230}$

While the new emissions benchmark sets an aggressive standard, and the consequences of non-compliance can be severe, the GGA was designed to give regulated facilities some flexibility with respect to their options for meeting their emissions limits. Among other things, the GGA and the Greenhouse Gas Emission Control Regulation provide for the use of "compliance units," which operators of LNG facilities can collect and use to satisfy the emissions benchmark. Compliance units include "offset units" (units obtained through a specific, province-approved emission offset project), "funded units" (units earned through payment of $\$ 25$ per unit to the province), "earned credits" (received as a result of emissions falling below the limit in a previous period), and "recognized units" (units obtained from a different jurisdiction recognized by the GGA). ${ }^{231}$ Facility operators must establish and maintain a "holding account" for compliance units credited to their respective facilities, and a "compliance account" into which the operator may transfer compliance units for the purpose of meeting the facility's compliance obligations. ${ }^{232}$ The GGA allows facility operators to trade and transfer compliance units with other facility operators in "compliance unit transactions," 233 which are tracked and recorded by the British Columbia Carbon Registry established by the Greenhouse Gas Emission Control Regulation. There are no restrictions on the number of compliance units that a facility operator can bank or transfer, or the number of funded units that it can purchase.

The GGA and the Greenhouse Gas Emission Reporting Regulation set out reporting obligations for regulated facilities in British Columbia (many of which have simply been imported and consolidated from previous legislation and regulations). Under the GGA regime, facilities that emit 10,000 tonnes or more of carbon dioxide equivalent emissions per year must report their greenhouse gas pollution each year, and all industrial emitters over 25,000 carbon equivalent tonnes per year must have their emissions verified by an independent third party. ${ }^{234}$ Specific rules and exceptions apply to industrial emitters whose emissions fall below the threshold of 10,000 tonnes. ${ }^{235}$

The GGA includes broad enforcement powers, including powers of inspection and administrative monetary penalties. It also creates a number of offences and provides for director and officer liability with respect to certain failures to comply with its provisions. Thus, although the emissions control regime established by the GGA is intended to be flexible in practice, it nonetheless has teeth when it comes to enforcing compliance amongst regulated facilities.

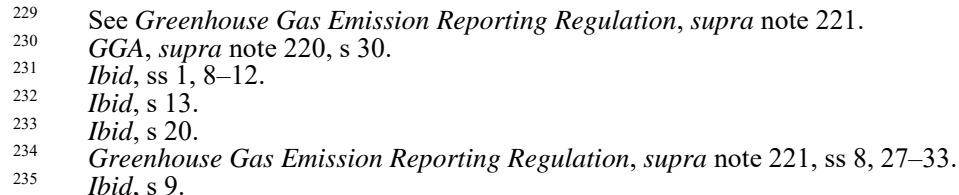


Some of the emerging criticisms of the GGA are that although the emissions benchmarks are ambitious, the GGA is too flexible in terms of the range of options it gives facility operators to meet them, and its focus on regulating GHGs generated by the facilities themselves means that it fails to address the upstream GHGs generated by the rest of the operations and activities associated with LNG production. ${ }^{236}$ For these reasons, some critics have argued that the GGA does not establish a truly effective climate action regime, and it will not have a meaningful impact in terms of assisting British Columbia to meet its legislated emissions targets. ${ }^{237}$ Others have questioned the "balancing act" that the GGA seeks to carry out, between reducing GHG emissions to meet the targets set out in the GGRTA and promoting LNG development at the same time, and expressed skepticism about whether both goals are truly achievable. ${ }^{238}$

Since the GGA has only been in force for a few months, and no major LNG projects in British Columbia are operational yet to test the new regime, it is too early to speculate as to whether any of these criticisms are accurate, or to comment on any "lessons learned" from the implementation of the new legislation. However, any potential issues relating to the focus of the GGA and the scope of the GHG emissions it regulates may now be less of a concern for critics, given the federal government's recent announcement that upstream GHGs will soon become a factor for consideration in the environmental assessment process for major infrastructure projects (such as LNG facilities and oil and gas pipelines) under the Canadian Environmental Assessment Act. ${ }^{239}$

\section{REGULATORY CONSIDERATION OF UPSTREAM GHG EMISSIONS}

On 27 January 2016, the Government of Canada announced that it was commencing a review of the current environmental assessment process, and would be implementing a new climate test for large infrastructure projects. ${ }^{240}$ Pursuant to the new test, large infrastructure projects will be assessed in light of their broader climate impacts, including their "[d]irect and upstream greenhouse gas emissions." ${ }^{41}$ Under the new framework, projects will be assessed not only with respect to the GHGs they are likely to generate, but also the GHGs that are likely to be generated by upstream activities linked to those projects. The Department of Environment and Climate Change has published the methodology that it intends to use to estimate the upstream GHG emissions associated with major oil and gas projects; however, the extent to which the estimated upstream GHG emissions will ultimately affect the government's decision in the environmental assessment process remains unclear. ${ }^{242}$ What is clear is that the proposed changes create a degree of uncertainty for proponents currently considering potential LNG projects in Canada.

Travis Lupick, “Environmentalists Deconstruct B.C. Liberals' New Rules for LNG Emissions, Argue It's All About Optics," The Georgia Straight (1 November 2014), online: <www.straight.com/news/ 761906/environmentalists-deconstruct-bc-liberals-new-rules-lng-emissions-argue-its-all-about-optics> . Ibid.

Peter Ladner, “B.C.'s Balancing Act: LNG Riches and Low-Carbon Commitments,” Business in Vancouver (5 April 2016), online: <www.biv.com/article/2016/4/bcs-balancing-act-lng-riches-and-lowcarbon-commit/>. SC 2012, c 19.

Government of Canada, "Government of Canada Moves to Restore Trust in Environmental Assessment" (27 January 2016), online: <news.gc.ca/web/article-en.do?nid=1029999>.

Ibid.

Department of Environment and Climate Change, Estimating Upstream GHG Emissions, (2016) C Gaz I, 786 . 
For LNG proponents looking specifically at British Columbia, the new GGA regime and the changes to the environmental assessment process present a very different regulatory landscape than they would have faced in the past. On its face, the GGA could well be capable of assisting British Columbia in meeting its emissions targets under the GGRTA, while simultaneously encouraging LNG development in the province. On the one hand, it has imposed an ambitious emissions benchmark for LNG facilities and has created robust enforcement mechanisms to ensure compliance, but on the other, the flexibility it affords to facility operators through the compliance unit scheme could make complying with the new benchmark a much more manageable commitment. That said, if the new environmental assessment process proves to be too onerous or uncertain for prospective LNG developers, it could undermine British Columbia's ability to implement the balanced regulatory framework it is seeking to establish through the GGA. Given that responsible LNG development comprises a key component of British Columbia's long-term economic plan, British Columbia can be expected to be a very interested and vocal stakeholder in the federal legislative process as it unfolds.

\section{FOCUS ON RENEWABLE ENERGY AS PART OF British COLUMBIA’s ClimATE ACTION STRATEGY}

In the meantime, BC Hydro is moving ahead with construction of the Site C Clean Energy Project, which will establish a third dam and hydroelectric generating station on the Peace River in northeast British Columbia. Once complete, Site C is expected to provide 1,100 megawatts of capacity, and produce approximately 5,100 gigawatt hours of electricity each year, which BC Hydro has stated will be enough energy to power the equivalent of 450,000 homes per year. ${ }^{243}$ Construction of Site $\mathrm{C}$ is scheduled to begin this summer and is expected to be complete in $2024 .^{244}$

Not surprisingly, the British Columbia government is positioning Site $\mathrm{C}$ as a key component of its climate action strategy. ${ }^{245}$ Given British Columbia's commitment under the GGRTA and the Clean Energy $A c t^{246}$ to reduce its GHG emissions and encourage the transition to clean, renewable energy sources, the introduction of a significant new source of clean, renewable hydroelectric power will be an important step in the right direction. The British Columbia government has stated that Site $C$ will not only be a significant new source of renewable energy on its own, the firm energy it will provide will also support the development of further independent power projects (IPPs) by backing up intermittent sources of power, such as solar or wind. ${ }^{247}$

Some of this new energy could be used to power British Columbia's LNG facilities, and thus assist in realizing the government's goal of ensuring that British Columbia has the “cleanest LNG facilities in the world." BC Hydro has already been asked to supply electricity

BC Hydro, "Site C Clean Energy Project" (2016), online: <https://www.sitecproject.com/about-sitec/project-overview>.

Ibid.

"2016 BC Speech from the Throne," supra note 224; Bailey, supra note 224. SBC 2010, c 22.

British Columbia, Office of the Premier, News Release, "Site C to Provide More Than 100 Years of Affordable, Reliable Clean Power" (16 December 2014), online: <news.gov.bc.ca/stories/site-c-toprovide-more-than-100-years-of-affordable-reliable-clean-power $>$. 
to Woodfibre LNG Limited's proposed LNG processing and export facility near Squamish (for use in the liquefaction process, among other things), and is currently exploring interconnection solutions. ${ }^{248}$ If transmission and distribution can be established to link BC Hydro's electricity system with LNG facilities operating in British Columbia, the clean energy produced by Site $\mathrm{C}$ could well assist those facilities in reducing their respective GHG emissions as required under the GGA. In this regard, the development and expansion of BC Hydro's electricity system can work together with the new regime established by the GGA as part of a larger, comprehensive strategy to reduce GHG emissions in British Columbia.

\section{Conclusion}

The economic, political, and social implications of Alberta's new focus on renewable energy development will not be fully known until the design and details of Premier Notley's Climate Leadership Plan continue to emerge. The scale of development required and the widespread impact on industry participants will make it difficult to achieve the government's stated objectives without a cohesive plan that reflects Alberta's unique history with respect to climate change, the lessons learned from other jurisdictions across Canada, and the demands of industry in Alberta's struggling economy. While only time will tell who the winners and losers in the new regime will be, it is clear that the policy changes will drastically alter how oil and gas companies and electric utilities do business in Alberta. 